\title{
CLASS AND CULTURE IN GERMANY
}

\author{
Michael Vester
}

\begin{abstract}
The article develops a typological map of the class cultures in Germany (including a short comparison with the typologies of France, Italy and Britain). It is based on ample qualitative research and representative surveys organised by a new, dynamic interpretation of the theory of class habitus and social space developed by Bourdieu. It's methodology centers on Durkheim's concept of "milieu" which unites the occupational and the cultural dimensions of class. Social classes are defined primarily not as aggregates of the official employment statistics but as aggregates of social action, i. e. as groups united and distinguished by common habitus, practices and tastes. However, the class cultures of everyday life do not translate directly into political or ideological cleavages. The main six ideological camps of the political field draw their adherents from different, though neighbouring milieus in distinct zones of social space. As a whole, the research supports the hypothesis of class differentiation and not of class erosion.
\end{abstract}

$\underline{\text { Keywords }}$ Class change, milieu, habitus, political cleavages.

In this article, there will be developed a typological map of class cultures in Germany. It is based on a series of research projects organised by a new, dynamic interpretation of the Bourdieu approach to class habitus and social space. In it's methodology, the research centered on Durkheim's concept of milieu which unites the occupational and the cultural dimensions. Social classes were defined primarily not as the aggregates of the official employment statistics but as aggregates of social action, i.e. as groups united by a common habitus and the respective patterns of practice and taste by which they distinguish themselves from other milieus. According to it's habitus type, each milieu follows specific strategies of the life course which also include specific educational and occupational goals and means and, when frustrated, their substitutes.

Thus, occupational positions are not eliminated from structural analysis - as some of the theorists of post-materialism, affluence and classlessness will have it. Instead, it is seen in a dialectical relation to the social group's practical self-definition. As will be shown, this multi-level approach unites the dimensions in their relations and therefore allows to locate each milieu in a multidimensional map of the occupational positions (fig. 3) as well as in historical maps which identify their descendence from older milieus and class cultures (fig. 4), in maps of the spatial configuration of milieus in society as a whole (fig. 5) and in maps of their political dispositions (fig. 6).

In this article, the presentation of German research on the dynamics of milieus is connected with the discussion of three questions: 
- How can the Bourdieu approach be utilized in different national contexts?

- How can the Bourdieu approach be related to the issues of social and cultural change?

- If habitus is the pivot of class analysis, how can research on habitus be methodologically carried out?

The milieu approach, as developed in Germany under the influence of Bourdieu and of English cultural studies, is only one of the contributions to solve the first question, concerning the transnational applicability. It seems that none of these efforts was content to only "apply" the Bourdieu approach, imitating it as it had been developed for the study of the apparently rigid class structures of France. Each of them tried, in interestingly different aspects, to develop, enlarge or modify Bourdieu's approach in order to enhance it's capacity to comprise more aspects of complex, advanced societies.

Michèle Lamont, in her study Money, Morals and Manners, compared four factions of the French and United States upper middle class, which comprise 10-15 per cent of the population. In her 160 semi-directive interviews in four regions, she went into the depth of the habitus patterns, using Bourdieu as a base (1992: 181, 275). Her results suggest "revisions of the main models of human nature currently in use in social sciences", especially the "ontological model of human nature" of Marxist, structuralist and rational choice theories which assume "that humans are essentially motivated by utility maximization, and that because economic resources are more valuable than other resources they are the main determinant of social action. " $(1992: 179,5)$ Focussing on different types of symbolic boundaries drawn by middle-class members, she found that moral boundaries are still very salient at the discursive level. In her view, even Bourdieu underestimates moral boundaries as compared to socio-economic and cultural boundaries. Mike Savage et al. (1992), in Property, Bureaucracy and Culture, studied three factions of the same middle class, analyzing the life-style survey data and other data of public-sector professionals, of managers and government bureaucrats and of "postmoderns" in parts of the more modern service occupations. Much like Lamont and contrary to Bourdieu, they also found a "non-distinctive" group and also stressed the importance of culture as an independent variable concerning class position and habitus. They also differ from Bourdieu's typology of capital assets by paying more attention to the organisational assets in middle-class careers which loose weight and to an increasing fragmentation of the middle classes.

Still another encouragement to widen the scope of the Bourdieu approach was formulated by Jan Rupp (1995, 1997), in Rethinking Cultural and Economic Capital, who suggested to pay more attention to the horizontal axis of Bourdieu's social space. In his study on the educational strategies of workers in the Netherlands, he noted a strong disposition for investments in the children's cultural capital which could be explained not only by vertical mobility striving towards petty bourgeois standards but also by a horizontal movement towards the left or intellectual pole of social space, towards more personal autonomy and emancipation. 
The implications of Rupp's study point to the second question, the capacities of the Bourdieu approach to explain change. Bourdieu's own work, especially in Distinction, mainly concentrates on the static aspects related to the reproduction of class. Post-materialism, affluence and modern life styles are regarded, but largely viewed from the perspective how classes change in order to conserve. This interpretation is evidently connected with Bourdieu's concentration on the upper classes and their petty bourgeois followers, which are, by definition, interested to defend their own elevated or elevating position. The dominated classes which, as we will see later, comprise more or less four fifths of the total population, are only treated in a short chapter, which hardly differentiates sub-groups. Here, Bourdieu's argument is mainly that of a sceptic realism, opposed to the naive intellectual idealisations of working class consciousness and rebellion forwarded by leftist and orthodox Marxists in the 1970s.

Rupp (1995, 1997), instead, centers on the emancipatory potentials and dynamics of the skilled working classes, as a development of cultural capital on the horizontal axis. Here, Rupp also formulates a missing link relating Bourdieu's class analysis to a central field of his research, the sociology of education. This parallels our own approach (Vester, 1992 and Vester et al., 1993, 2001), which sees class dynamics in the contradiction of cultural processes on the horizontal axis and power relations on the vertical axis of social space. The concepts of the axes of social space can be enlarged, when they are related to the underlying theoretical concepts of division and labour or differentiation (horizontal axis), of domination and counter power (vertical axis), of the differentiation of institutional field levels (third axis) and of time, as the medium of social practice (fourth axis). These theoretical differentiations which are elaborated elsewhere (Vester et al., 2001, Vester, 2002) will be treated in this article mainly implicitly, in connection with the methodology of our research.

The third question is how the naive intellectual schematisms as criticized by Lamont could be overcome by a methodology of typological habitus analysis. Following the English culturalists, especially Raymond Williams (1963), E. P. Thompson (1963) and Stuart Hall (Hall and Jefferson, 1977), it was possible to develop the necessary hermeneutic methods. Combining it with Bourdieu's approach, we could attempt to redefine the relation between occupation and habitus types, trying to solve the problems pointed out by the critics of the "employment aggregate" approach, especially by Rosemary Crompton (1998).

\section{The steps of milieu research}

Our research was carried out in a series of studies since 1987. The basis was laid in a first, larger project, supported by the Volkswagen Foundation. Designed after the Bourdieu approach, it combined three levels of analysis. The most important level was the qualitative analysis of intergenerational change of class habitus in the new 
social milieus. It's results, explicated later, supported the thesis that the new life styles and habitus did not constitute a radical rupture but a relative modification of the older class habitus identities. To find the causes and conditions of this modification, it was related first to a separate statistical analysis of occupational change in Bourdieu's multidimensional social space. The data showed a strong movement towards the left, "cultural" pole of social space. Was this the cause of habitus change, as supporters of the employment aggregate approach suggested? Or was it produced autonomously by the social milieus and movements, as the theorists of individualization assume? To test this second hypothesis, we made three regional case studies of the new social movements and their habitus changes.

Our research finally confirmed the hypothesis that the change of class habitus was not the result of monocausal dynamics, either of occupational change (as suggested, e.g., by Bell or by Giddens) or of individual self-activity (as suggested by Beck), but it was influenced by both, in their status of necessary, but not sufficient causes of societal change.

In order to assess the relative impact of the different forces, we had to develop research instruments, which could relate these levels systematically for the whole society. The only approach available to interrelate the societal dimensions was that of Bourdieu (1992). Among these instruments, explained below, there was a specific survey instrument, the 44-statement Milieu Indicator developed by the Sinus Institute in Heidelberg, which promised to explore the main habitus and life-style types of society (see SPD, 1984). Used in our representative survey, it offered us a complete typology of milieu or habitus types, their relative size and the distribution of the important demographic and socio-economic variables in the milieus.

This map of the totality of class milieus, however, cannot be used in an isolated manner expecting automatic solutions. It had to be treated with care, keeping in mind the limits of "indicators" which only indicate something that has to be studied separately and directly. To avoid the risk to construct statistical artefacts, we therefore mainly used the milieu indicator as a heuristic instrument, i.e. a tool for further qualitative research into the milieus and their habitus. In our basic study we only had studied the small segment of the "new" or "alternative" social milieus going back to the 1968 movements. To explore these possible ten per cent of the total population, we had to invest the work of about 250 long qualitative interviews, which had to be interpreted at length to find out the habitus structures of each case.

To fill the other white spaces in the map of milieus, a series of subsequent research projects was undertaken for which support was not always easy to be raised. The most important of these projects were a study on the East German milieus, conducted in the early nineties (Vester et al., 1995), a later study on workers' education (Bremer, 1999) and a study on the milieus addressed to by the protestant church (Vögele, Bremer and Vester, 2002). In these qualitative studies, we mainly concentrated on the milieus formerly associated with the working class milieus and the labour movements and on their upper neighbours, the milieus of higher education and services. By these, we could cover more or less 60 per cent of the total population, developing a first typology, which still has to be improved by further differentiation of sub-groups. 
Step by step, a highly dynamic differentiation of the modernizing milieus of the popular and employee classes was discovered. In the gradual progress of research, it was also necessary to test and revise the theoretical and methodological tools. We soon observed that our original maps of social space did not allow a consistent placing of the milieus of skilled work and their "family tree". This was only possible after a new statistical analysis of these milieus (Vester, 1998) which helped to overcome the inconsistencies by the improved concept of axes still in use (Vester et al., 2001). Solving problems of consistency also makes clear that much work still has to be done to continue exploring the inner differentiation of the milieus found and also to explore the still missing third of the population, i.e. the more traditional and conservative milieus in the right part of social space. ${ }^{1}$

\section{Research questions and methodology}

The basic research project, ${ }^{2}$ was designed as an empirical test of the hypotheses on the dissolution of class and class culture, as presented by Ulrich Beck, Anthony Giddens and post-modern sociology. In it's qualitative parts, we concentrated on the new social movements and milieus which were supposed to exemplify this dissolution by a habitus of humanistic values "beyond class" (Offe, 1985). In further steps, we widened our scope to West German social space as a whole which was analysed with the help of the national occupational statistics as well as our own representative survey of 1991 and the named subsequent studies and secondary data analyses.

The research questions and the design of the project were following the multi-level field concept of Bourdieu by first analysing three main fields (habitus change, occupational change, and the change of social cohesion) separately and finally integrating these fields. The methodology could not be taken ready-made from Bourdieu. ${ }^{3}$ The following short summary may give some impression of the operational dimensions developed during the research process.

1 This work is presently organized in a project on the inner differentiation, also by gender, of the two central "family trees" of the milieus, the tradition line of skilled work and the tradition line of the petty bourgeois popular classes (see Vester, 1998; Vester et al., 2001: 55-57).

2 The project "Social structural change and the new socio-political Milieus", carried out at the University of Hannover from 1988 to 1992, was especially supported by the Volkswagen Foundation. The study and it's methodology are documented in Vester et al., 1993, 2001. East German society was not included because the German Democratic Republic was not accessable when the project began in 1988 and, moreover, it constitutes a different variant of social structure, which we studied in a separate project (Vester et al., 1995).

3 As shown more completely in our book, we had to develop the specific hermeneutics of typological habitus analysis (Vester et al., 2001: 215-218, 311-369), the operational criteria of positioning occupational groups (ib.: 219-221, 373-426) and habitus groups (ib.: 26-64) in social space and an analysis of the field dynamics of social movements (ib.: 221, 253-279). Also newly developed was the design of a representative survey combining attitude and socio-statistical variables according to Bourdieu's theory and to the four axes of social space (ib.: 221-250, 427-502). 
The main part of the project (point 3. in the synopsis of fig. 1) asked for the intergenerational habitus or mentality ${ }^{4}$ change: Was it true that the alternative milieus and the new social movements represented a new "universalist" habitus and practice which was no more linked to particular class milieus?

In our habitus analyses we took the opposite procedural direction as Bourdieu took. Bourdieu mainly started with the occupational group and then asked what life style attributes and practices it's members preferred. From these, then, he reached, by interpretation, the habitus patterns. Interviews were mainly used to exemplify these habitus patterns. This procedural direction certainly contributed to Bourdieu's alleged economic determinism. Our main starting point, instead, were the attitude patterns themselves which we found by the interpretation of large samples of non-directive biographical interviews. Only after having found the habitus type, we asked which occupation, social relations etc. were "typical" or "not typical" for it.

The sample of the new social milieus was recruited according to a specific "scouting" procedure in the three selected regions, choosing people with distinctive attributes and practices of the life style of the new social milieus (ib.: 328). The sample consisted of 24 interviews for the initial non-directive biographical interviews (which had a length up to five hours) and the subsequent 220 semi-directive interviews, controlling informally that the five basic fields of experience were covered (see point 2.3. in fig. 1). For the detection of habitus change we interviewed two generations. Considering the gender differences of habitus, the female half of the sample was interviewed as compared to the mothers and the male half as compared to the fathers.

The habitus types were reached at according to the syndrome concept. By an intensive procedure of text interpretation, the "schemes of valuation, classification and action" (Bourdieu) and their interrelational structure in a comprehensive habitus syndrome were extracted. The procedure followed the rules of sequence analysis, i.e. the hermeneutic interpretation of only a few lines of text at one time by a selected interpretation group which had to discuss and note all variants of interpretation. In later stages, special attention was given to the balance of these patterns according to dimensions like "ascetic vs. hedonistic", "dominance vs. partnership" (also in gender relations), "isolation vs. cohesion", "popular vs. distinctive taste" etc. Finally, the single habitus traits found in the interpretation had to be analyzed as to their syndrome structure: How were the single traits related, which traits had priorities (or a status of goals) and which traits were representing competing goals or mere means etc?

Habitus structure can be understood as organized like the ethics of everyday life, defining which values should come first in social practice (e.g., work before

4 German sociology is mainly following the terminology of Theodor Geiger, who already in 1932, in the first "panoramic" analysis of German social structure and class mentalities, uses the term "mentality" which he defines interchangably with "habitus" (Geiger, 1932: 13-16, 77ff; see also Rüschemeyer, 1958). To avoid misunderstandings, we are generally using the term habitus, in this article. 


\begin{tabular}{|c|c|c|}
\hline $\begin{array}{l}\text { 1. Milieus and social practice } \\
\text { 1.1. Dynamics of cohesion and distinction } \\
\text { in new social milieus }\end{array}$ & $\begin{array}{l}\text { 2. Occupational structures } \\
\text { 2.1. Reconstruction of the space of social } \\
\text { positions since } 1950\end{array}$ & $\begin{array}{l}\text { 3. Habitus and life styles } \\
\text { 3.1.Patterns of social classification in the } \\
\text { new milieus }\end{array}$ \\
\hline $\begin{array}{l}\text { Exploration of three selected regions } \\
\text { (Hannover, Oberhausen, Reutlingen); } \\
\text { expert interviews, document analyses; } \\
\text { elaboration of 'milieu biographies': phases } \\
\text { and patterns of development and cohesion } \\
\text { of 'alternative' life style and movement } \\
\text { milieus. } 4-12 / 89 ; 6 / 91-2 / 92\end{array}$ & $\begin{array}{l}\text { Delimitation of } 163 \text { occupational groups } \\
\text { according to Bourdieu's capital types; data } \\
\text { collection and catalogization of qualitative } \\
\text { characteristics of each group; } \\
\text { agglomeration and positioning of } 102 \\
\text { groups in soc. space; topics and dynamics } \\
\text { of occup. Structure. } 9 / 88-5 / 89 ; 9-12 / 89 ; \\
3-6 / 92\end{array}$ & $\begin{array}{l}\text { Qualitative content analyses of documents } \\
\text { of everyday culture (classification and } \\
\text { valuation patterns in comics by Brösel, } \\
\text { Poth, Fr.Beker, Seyfried, in advertising, in } \\
\text { attributes of the life style etc.); testing the } \\
\text { patterns found in group discussions in } \\
\text { three selected sub-milieus. } 9 / 88-3 / 89\end{array}$ \\
\hline \multicolumn{2}{|c|}{$\begin{array}{l}\text { 1.2. (= 2.2.) Regional socio-structural change } \\
\text { Expert interviews; collection of data and documents; analysis of the phases of } \\
\text { socio-economic modernization and the iopening of social space since 1950; } \\
\text { comparison of regional development problems of de-industrialization (Oberhausen), } \\
\text { tertiarisation (Hannover) and industrial modernization (Reutlingen); analysis of local } \\
\text { social and electoral structures. } 10-12 / 88 ; 5-8 / 89 ; 3-8 / 91\end{array}$} & $\begin{array}{l}\text { 3.2. Habitus syndromes and generational } \\
\text { change } \\
\text { Non-directive biographical interviews in } \\
\text { the } 3 \text { regions: sample of } 12 \text { women and } \\
\text { men of the new milieus plus } 12 \text { parent } \\
\text { interviews of same sex; sequence } \\
\text { analyses and hermeneutic interpretation } \\
\text { of the transcripts concerning persistence } \\
\text { and change of habitus patterns. } 3 / 89-1 / 90\end{array}$ \\
\hline 1.3. Urban q & \multicolumn{2}{|l|}{ 2.3. $(=3.3$.$) The field of new habitus types$} \\
\hline $\begin{array}{l}\text { Expert interviews, document collection } \\
\text { and observation concerning attributes, } \\
\text { practices and topologies of everyday } \\
\text { culture and social cohesion of milieus in } \\
\text { selected urban quarters (subsequent } \\
\text { research projects in Hannover) }\end{array}$ & \multicolumn{2}{|c|}{$\begin{array}{l}220 \text { narrative interviews of } 2-3 \text { hours focussing on five spheres (work and occupation; } \\
\text { family and partnership; leisure, life style and social relations; views of society and } \\
\text { ideologies; socio-political participation) with members of the new milieus and one } \\
\text { parent of the same sex (plus standardized questionnaire and observation resp. } \\
\text { photographs in the home); interpretation and construction of five habitus types. } \\
1 / 90-5 / 91\end{array}$} \\
\hline
\end{tabular}

\section{Social space as a whole \\ 4.1.Macro-analysis of social space}

Proportions, structures and dynamics of social milieus, occupational groups and socio-political camps: representative survey "Socio-political milieus in West Germany": development of the analytical instruments concerning social situations, occupational positions, habitus, cohesion patterns in their temporal and intergenerational change; June/July 1991 by the Marplan Institute; basic results; cluster- and factor analyses for the identification of types of habitus, cohesion and socio-political camps; identification of modernizing zones in social space. 1/1991-7/1992, continued later

4.2. Interpretation of the basic patterns of the topics and dynamics of social space as a whole on the base of all four project parts; integration in a concept of a "pluralised class society" (1 - 12/92), published in Vester et al., 1993.

4.3. Towards a completion of the qualitative milieu typology

Using the basic patterns or general map of class milieus as a heuristic tool, the qualitative analyses of habitus types and their historical tradition lines were completed step by step in subsequent projects on the other zones of social space, especially the three 'family trees' of the popular classes and of higher Education; in a project on workers' ecducation (published in: Bremer 1999) using the methodologies of focussed narrative interviews (see 2.3.) and the newly developed tool of the 'group workshop', and in a project on the protestant church and the social milieus in Lower Saxony (published in: Vögele, Bremer and Vester, 2002).

4.4.Completing a revised version of the macroanalysis of social space

The enlarged typology of milieus and their family trees (see 4.3. and Vester et a. 1993) and a multivariate statistical analysis of the Meritocratic Employee Milieu (published in Vester et al., 2001) revealed contradictions in the first concept and maps of social space (see 4.2.). The problems were solved by a revised theoretical definition of the concept of the four axes of social space (see Vester et al., 2001). A subclustering of the milieus of the initial survey (see 4.1.) was done along these axes and produced a better compatibility of the qualitative and the survey-based typology of now 20 milieus, grouped in 5 milieu tradition lines (see Vögele, Bremer and Vester, 2002).

Figure 1 Research project "Change of social structure and new social milieus" (1988-1992) and it's completion by subsequent research 
leisure) and which should come to their right, later. In the milieus of skilled work, e. g., personal autonomy is the primary goal, but embedded in a context of dispositions for learning, good work performance, solidarity, mutuality, social justice etc. By this contextual interpretation the classification of the working classes by isolated properties can be replaced. These properties, e. g. physical work or collectivism, which lay at the base of the intellectual myth of the proletariat, are seen to be traits which do occur under special conditions but are not essential for class identity. The complete syndrome structures are exemplified in the typological descriptions, later in this text.

The attitude syndromes were first analysed for each case separately. In a second step, the individual cases had to be grouped to types according to their different syndrome structures. ${ }^{5}$ The cases of our sample could be easily separated into five habitus syndromes or types of the new social milieus, which could be easily distinguished by their basic structures. For each of the five types a portrait was formulated (2001:331-363). Later, the types could be identified as the youngest and most radical parts of already existing parent milieus. Most interesting among these newly discovered types was the Modern Employee Milieu, a descendant of the Traditional Working Class Milieu, which grew to 8 per cent of the population, until 2000.

The habitus types of the younger generation were not completely different from the parent generation, as the individualisation thesis supposes, but variations of the same basic patterns which. This confirmed our initial hypothesis of a generational habitus metamorphosis, which had been inspired by the Birmingham cultural studies (Hall and Jefferson, 1977). To find the generational similarities was mainly possible because each type could be formulated in rather general terms of the "moral" and "symbolic" meaning - and not by the surface attributes and practices of life style, which expectedly differed between the generations.

The next part of the study (no. 2 in fig. 1) asked for the dynamics of the occupational field: How was habitus change linked to changes in the occupational and economic position? And where was this occupational change to be located in the total occupational change of West Germany? The changes of the occupational field since 1950 were analysed by processing the available occupational data according to the "ascending method" of Geiger (1932: 17f) and Bourdieu's concept of social space.

Geiger's method was designed to avoid a main fallacy of the employment aggregate approaches. Geiger did not start with the larger occupational categories but split them into smaller, elementary groups, in order to get more adequate approximations to the cultural and practical dimensions of occupational groups. The new groups were less heterogeneous in the specific properties of professional

5 They were not grouped according to types already existing, e.g. in the typologies of Williams (1963) or Bourdieu (1992). They were also not grouped according to single traits, e.g. individualization or post-materialism. Not single statements or attitudes but the interrelation of the statements, the structure of their syndrome as a whole concept of an everyday ethic (Weber), allowed to group them together. To find a valid typological structure, a maximum of about twenty cases was necessary. Additional cases gave little additional information. 
situation, income, tradition, organizational status etc. After this, Geiger regrouped them one by one into larger, more homogeneous units, thus "ascending" from the single, elementary group to possible larger units. By analysing 163 occupational groups this way, ${ }^{6}$ we could map a selection of important occupational fields, especially in the sectors of the educational, health, technical and agricultural occupations - also divided by gender cleavages (Vester et al., 2001: 413-422).

The principal result of this part of the study was that, according to the data since 1950, there was a significant movement from the right to the left pole of social space. This supported the hypothesis of a historical drift towards more cultural capital on all vertical levels of society. These findings had important consequences for the theories of the tertiary knowledge society (Bell, 1973). On the one hand, these tendencies were strongly represented in the data, showing a rise of tertiary occupations from about 20 to almost 60 per cent up to 1990. But this growth mainly remained a horizontal movement which did not basically change the vertical relations of domination between social classes - and also the gender, age and ethnic classes. As a consequence, it could be seen that classes, whether occupational or cultural, did not erode but only move to the left part of social space. This implies that social conflict, too, did not disappear but move towards a new level of class conflict, based on the higher competences and aspirations for autonomy in the popular milieus.

The third part of the study (point 1 in fig. 1) was dedicated to the logic and patterns of the change of everyday culture and of political camps: How did the milieus of the new social movements develop their cohesion and identity since the end sixties? Case histories in the three regions showed by which logics, especially dynamics of conflicts and coalitions, the new movements and milieus had developed in the regional field of socio-political camps.

The main finding of this part of the study was that protest action primarily did not arise according to a logic of repression, material or moral deprivation or marginalisation, as the conventional hypotheses will have it. Also, the new identities were not only linked to occupational change, as the employment aggregate approach suggests. Almost half of the persons interviewed in the survey who shared the new, more qualified and modernized occupational profiles did not share the new habitus dispositions. This supports the hypothesis that habitus change was due to a more general change in the societal field of forces, i.e. the "opening of social space" for hitherto unrealized or unrealizable "designs of life" (according to the theory of Merleau-Ponty (1965: 503-508) and to the social and political conflicts between the generations (see Hall and Jefferson, 1977) since the sixties.

The last part (point 4. in fig. 1) aimed at a synthesis, i.e. the changes of the class configuration as a whole: How did the dynamics of the different fields, studied separately in the first parts, correlate? How representative were the selected milieus for social

6 Each group was assessed according to a catalogue of eleven socio-economic properties: size and change of size since 1950, gender, age, educational and occupational diploma, occupational position, economic sector, main activity, weekly working time, net income of full and part time employed, immigrant quotas, incidence of unemployment (ib.: 381). 


\begin{tabular}{|c|c|c|}
\hline 1. Habitus and politics & \multicolumn{2}{|l|}{$\begin{array}{l}\text { Everyday culture (1.1. -1.3.) and } \\
\text { socio-political orientations (1.4.-1.6.) }\end{array}$} \\
\hline ANALYTICAL CATEGORIES & NO. \& CONTENTS OF QUESTION & INTERROGATION MODEL/TIME (MIN.) \\
\hline 1.1 Habitus (mentality types) & $\begin{array}{l}\text { (1) basic attitudes towards everyday culture } \\
\text { aspects (work/leisure motivation, } \\
\text { hedonistic/ascetic preferences, gender and family } \\
\text { relations, technological progress and politics) }\end{array}$ & $\begin{array}{l}\text { "milieu indicator", with } 44 \text { statements and a four } \\
\text { degree scale of consent and dissent, developed } \\
\text { by, used with permission of and data-processed by } \\
\text { the Sinus institute, Heidelberg (12) }\end{array}$ \\
\hline 1.2. Social cohesion (styles of gregariousness) & $\begin{array}{l}\text { (7) basic attitudes towards social relations with } \\
\text { family, friends and acquaintances }\end{array}$ & $\begin{array}{l}\text { "indicator of cohesion", with } 39 \text { statements } \\
\text { (developed from the project's qualitative } \\
\text { interviews) and a four degree scale of consent and } \\
\text { dissent (10) }\end{array}$ \\
\hline 1.3. Leisure practices (places of activities) & $\begin{array}{l}\text { (13) frequency and scope of different gregarious, } \\
\text { social, cultural and political leisure actrivities } \\
\text { (social places and circles) }\end{array}$ & $\begin{array}{l}\text { list of } 22 \text { items and a scale of six degrees of } \\
\text { activity (6) }\end{array}$ \\
\hline 1.4. Socio-political camps (political styles) & $\begin{array}{l}\text { (12) basic attitudes towards the social and political } \\
\text { order (social justice, political participation and } \\
\text { representation, socio-political cleavages) }\end{array}$ & $\begin{array}{l}\text { "indicator of political styles", modified by the } \\
\text { project, with } 45 \text { statements and a four degree } \\
\text { scale of consent and dissent (10) }\end{array}$ \\
\hline 1.5. Political participation & $\begin{array}{l}\text { (P) degree of interest in specific political issues } \\
\text { (4) party sympathies } \\
\text { (8) vote in } 1987 \text { general election } \\
\text { (14) vote in } 1990 \text { general election }\end{array}$ & $\begin{array}{l}\text { closed question, five alternatives }(0,5) \text { five cards } \\
\text { for party ranking }(0,5) \\
\text { closed qn., nine alternatives }(0,5) \\
\text { closed question, } 12 \text { alternatives }(0,5)\end{array}$ \\
\hline 1.6. Socio-political tradition lines & (15b) trade union membersh.of father & open question $(0,5)$ \\
\hline 2. Social situations and positions & \multicolumn{2}{|l|}{$\begin{array}{l}\text { community status - Vergemeinschaftung (2.1.-2.4.) and } \\
\text { societal status - Vergesellschaftung (2.5.-2.6.) }\end{array}$} \\
\hline ANALYTICAL CATEGORIES & NO. \& CONTENTS OF QUESTION & INTERROGATION MODEL/TIME (MIN.) \\
\hline $\begin{array}{l}\text { 2.1. Type of "Vergemeinschaftung" } \\
\text { (household and family type) }\end{array}$ & $\begin{array}{l}\text { (2) family status } \\
\text { (9) permanent partnership relation } \\
\text { (3) way of living together (with } \\
\text { partner/parents/children/friends/alone) } \\
\text { (L) no. of persons in household } \\
\text { (M) age of the household members }\end{array}$ & $\begin{array}{l}\text { closed question, four alternatives }(0,5) \\
\text { open question }(0,5) \\
\text { closed question, four alternatives }(0,5) \\
\text { open questions }(0,5) \\
\text { open question (1) }\end{array}$ \\
\hline 2.2. Status in "Vergemeinschaftung" & $\begin{array}{l}\text { (A) gender } \\
\text { (B) age } \\
\text { (16) religious affiliation }\end{array}$ & $\begin{array}{l}\text { (noted by interviewer) } \\
\text { open question }(0,5) \\
\text { closed question, four alternatives }(0,5)\end{array}$ \\
\hline $\begin{array}{l}\text { 2.3. Societal status of partner } \\
\text { (social, cultural, econ. capital) }\end{array}$ & $\begin{array}{l}\text { (10) present occup. status of partner } \\
\text { (11) present or last occup.of partner }\end{array}$ & $\begin{array}{l}\text { closed question, } 11 \text { alternatives }(0,5) \\
\text { open question (coded according to occup. } \\
\text { statistics) }(0,5)\end{array}$ \\
\hline $\begin{array}{l}\text { 2.4. Territorial milieu } \\
\text { (region, location, home) }\end{array}$ & $\begin{array}{l}\text { (Q) size of building (no. of homes) } \\
\text { (-) size of location (political) } \\
\text { (-) federal state }\end{array}$ & $\begin{array}{l}\text { (noted by interviewer) } \\
\text { (noted by interviewer) } \\
\text { (noted by interviewer) }\end{array}$ \\
\hline $\begin{array}{l}\text { 2.5. Social status of the interviewed person } \\
\text { (cultural and economic capital) }\end{array}$ & $\begin{array}{l}\text { (C) highest school diploma achieved } \\
\text { (D) highest occ.diploma achieved } \\
\text { (E) present occupational status } \\
\text { (F) present or last occupation } \\
\text { (G) occupational activity field (producing, } \\
\text { transporting, office etc.) } \\
\text { (H) present or last occup.position } \\
\text { (K) resources of living } \\
\text { (O) personal net income (monthly) } \\
\text { (N) household net income (monthly) }\end{array}$ & $\begin{array}{l}\text { closed qn., seven alternatives }(0,5) \\
\text { closed question, six alternatives }(0,5) \\
\text { closed question, } 12 \text { alternatives }(0,5) \\
\text { open qn.(coded by occ.statistics) }(0,5) \\
\text { closed question, } 17 \text { alternatives }(0,5) \\
\text { closed question, } 26 \text { alternatives }(1) \\
\text { closed qun.for } 2 \text { of } 10 \text { alternatives }(1) \\
\text { closed question, } 12 \text { alternatives (1) } \\
\text { closed question, } 12 \text { alternatives (1) }\end{array}$ \\
\hline $\begin{array}{l}\text { 2.6. Social status of the parent and grand parent } \\
\text { generations } \\
\text { (intergenerational mobility) }\end{array}$ & $\begin{array}{l}\text { (5) school diploma of father/mother } \\
\text { (6) last occupational status of father, mother and } \\
\text { grandfathers }\end{array}$ & $\begin{array}{l}\text { closed question, } 7 \text { alternatives (1) } \\
\text { closed question, } 26 \text { alternatives resp. additional } \\
\text { question (2) }\end{array}$ \\
\hline
\end{tabular}

Figure 2 Analytical categories and instruments of the representative survey 
structure as a whole? What was their size and location in relation to the other social milieus? These questions were studied by the representative survey of the 1991 West German population.?

Constructing the multi-dimensional questionnaire according to the Bourdieu approach (see fig. 2 and Vester et al., 2001: 222-244, 546-557), each interviewed person could be located on all field levels simultaneously. For each level we could construct independent maps - and then see which types of habitus were related to which types of occupation, social cohesion, ideological camp etc. (Hall and Jefferson, 1977). A central prerequisite was to find a possibility to identify the class milieus by their habitus types. For this we were permitted to use the 44 statement milieu-indicator developed and validated by the Sinus Institute (ib.: 546-548). This indicator had been constructed to relate qualitative habitus analysis to habitus detection by standardized methods. Without such an instrument representative surveys could not disclose what proportion of the total population belonged to the habitus types originally found by qualitative interviews (carried out as described above). Initially, the Sinus Institute had extracted the statements of the indicator from large numbers of non-directive interviews. It was soon clear that the multidimensionality of the types did not allow batteries with less than forty statements. The answers are processed by a special clustering procedure, which fixes the centers of the clusters in order to reproduce the types in follow-up surveys.

When Sinus developed the indicator around 1982, the validity of the types was tested by various validation procedures and by applying the indicator to a so-called calibrating sample, i.e. a sample which before had been typologically analysed by qualitative interviews. Meanwhile, the indicator has been successfully applied for samples adding to more than 60.000 .

In our own research, we used the indicator mainly as a heuristic tool for two different purposes. First, it helped to quantify, on a representative level, the milieu types which we had found by qualitative methods, before. Second it helped to define the sample for qualitative research in those parts of social space about which we did not yet have sufficient knowledge. This latter procedure was especially used in our studies on the target groups of trade union adult education and of the Protestant church (Bremer, 1999, Vögele et al., 2002).

This also helped us to correct inconsistencies of the Sinus model. In general, the milieu indicator produces valid distinctions between the different types of milieus. It is evident that the differences between hedonistic and ascetic milieus are based on clear qualitative differences of the everyday ethics, which can also be easily reproduced by statistical procedures. However, there are also milieus and sub-milieus where the analysis of differences is more complicated. This was especially the case between certain milieu factions of the Meritocratic Employee Milieu and the Modern Petty Bourgeois Employee Milieu. Qualitative research revealed that these sub-factions both believe in social hierarchies, which, however,

7 The interviews were made in June and July of 1991 by the Marplan Institute, with a random sample of 2.699 German speaking inhabitants of 14 years and older, representative according to the demographic structure of the 1988 micro census. 
for the first group is based on personal work achievement ("leistung") and for the second group is based on hierarchical relations of loyalty. But, in modern German milieus, hierarchies are not openly legitimated by other than work achievement criteria. It was, however, possible to find the underlying differences by clustering procedures splitting the milieus into more homogeneous sub-groups which allowed a re-grouping. ${ }^{8}$

In our survey, additional dimensions of habitus were explored by three other item batteries and with questions concerning political and trade union participation as well as trade union participation of the parent generation (see fig. 2).

From the habitus types we proceeded to the second level, the occupational field. Thus, we could identify the typical occupational profile of each milieu. It is important to note that none of these profiles followed the distinctions of the official statistics, i.e. between production and services, secondary and tertiary sectors, blue and white collar etc. Instead, according to the data, the occupational profiles of the milieus rather followed (in a loose but clearly significant relation) the capital dimensions of Bourdieu. When we locate the milieus in Bourdieus map (fig. 3) we see that no milieu is exclusively limited to a single occupational aggregate. Instead, each milieu spreads over a certain zone of social space, which covers occupations with similar combinations of cultural and economic capital.

Our hypothesis had been that habitus changes might at least in part be related to a secular increase of educational and cultural capital - and in the growth of occupations requiring high standards of cultural capital, on the horizontal axis of social space. Our results confirmed this horizontal movement. As already noted, only about one half of the people who took part in this movement also could be counted as part of the modernized younger mentality types. This confirms the assumption that the mere growth of cultural capital and a respective leftward movement of the social position may well be a necessary cause of modernized habitus. But it is not a sufficient cause. It presumably will not lead to a more autonomous and less hierarchical habitus when the biographical conflict, the active sub-cultural struggle for emancipated life-styles is not waged.

As will be summed up at the end of this article, our empirical data confirm that criticism of the employment aggregate approaches to class analysis, as discussed especially by Rosemary Crompton (1998), is highly justified — and that the Bourdieu-based milieu approach can help to solve several of these problems.

\section{The field structure of social space}

To understand milieu change, it is especially important to understand how the total map of class milieus or class cultures may be structured. We could show this by three ways to locate the milieus.

8 The analysis of the two types, which was made by Gisela Wiebke, is to be found in Vögele et al., 2002, pp. 338-356, 371-376. 


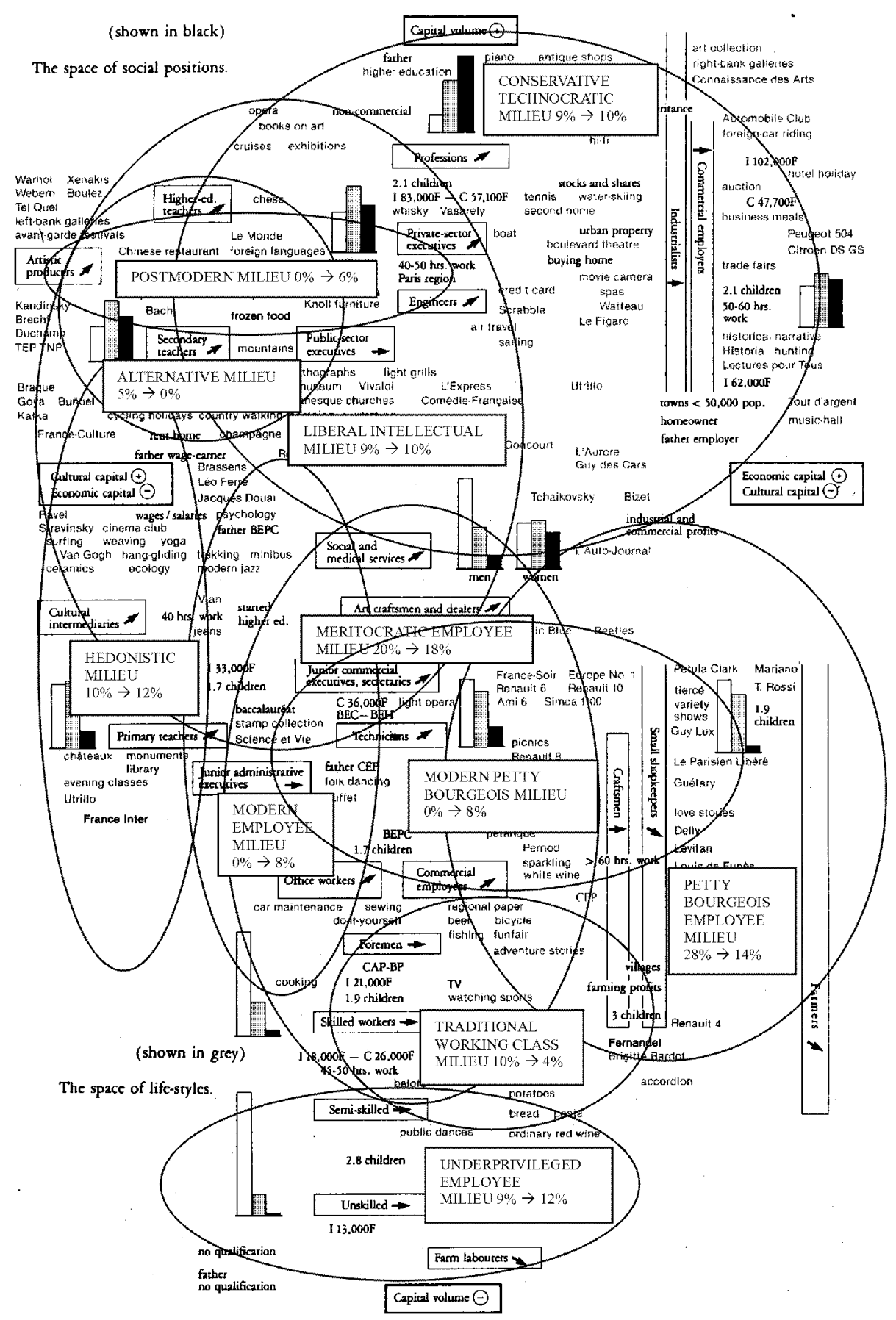

Figure 3 Location of the milieus in Bourdieu's space of occupational positions 
The first way, shown in fig. 3, is to locate each milieu in Bourdieu's social space according to the occupations of it's members. The elliptic lines surround the field zones in which the majority of each milieu have their occupational position. There is a certain spreading but also a centre of gravitation in the field. Three of the milieus are dividing the upper part of space among themselves. One of the milieus is confined to the lower pole of space. Five of the milieus share the middle. They are highly differentiated on the horizontal axis, from a shrinking petty bourgeois employee milieu in the right half to growing Modern Employee Milieus in the left half.

This first map (fig. 3) clearly shows a relative homology between economic and habitus position. The positions the milieus take in the division of labour are corresponding to a sort of functional division between the other activities of life as structured by the habitus. Apparently, life style and habitus, as distinctive signs and practices by which milieu members are finding a common identity and are distinguishing themselves from other milieus, are the expression of a field of structured social relations and tensions which are based on complementary positions of the milieus.

In the second graph (fig. 4) we have grouped the milieus synoptically together to show their historical tradition lines as well as their internal differentiation. In the case of the "respectable popular classes", the data allow to show a habitus metamorphosis manifested in a sort of family tree. The tradition line of skilled work (no. 2. 1. - the offsprings of the classical working class) consists of three generational groups: the vanishing old generation of the Traditional Working Class, the big, but stagnant middle generation of the Meritocratic Employee Milieu and the growing younger generation of the Modern Employee Milieu. This pattern of generational modernization does also show, in different degrees, in Britain, France, and Italy (annexes A1, A2, A3) for which we have the Sinus milieu data (see Vester et al., 2001: 34-36, 50-54).

The third graph (fig. 5) is structured not by the occupational positions but by the habitus types. For this positioning we recurred to the implicit principles of distinction by which each group delimitates itself from the other groups and which are described in the next parts of this article. The top is taken by three milieus around 20 per cent who distinguish themselves from the ordinary or popular milieus below them by their valuation of higher education and culture and the competences of taste. Below this line of distinction we find the "popular classes" (about 70 per cent) for whom qualified work or a secure and respected social status is the base of self-respect. Below them, we discover the milieus of the "underclass", with poor education and skills (about 10 per cent). They are less respected also because of their cultural habits adapted to a situation of insecurity and powerlessness. They are below what we may call the line of respectability.

Curiously enough, this vertical proportioning of society (20: 70: 10) supports what Goldthorpe et al. (1968) found out in the 1960's about one of the images of society: a strong respectable middle, topped by the rich and powerful and substratified by the underprivileged.

In the same map, we can also see a horizontal division of three zones separated by two cleavage lines. A cleavage line of authoritarian status orientation 


\begin{tabular}{|c|c|}
\hline $\begin{array}{l}\text { Vertical class pyramid and it's horizontal } \\
\text { differentiation by tradition lines }\end{array}$ & $\begin{array}{l}\text { Differentiation of the tradition lines by sub-groups } \\
\text { resp. generations in West Germany }(1982-2000)\end{array}$ \\
\hline \multicolumn{2}{|l|}{$\begin{array}{l}\text { 1. Dominant Milieus } \\
\text { [subdivisions corresponding to 'upper service class' } \\
\text { (a) and 'lower service class' resp. 'middle class' (b)] }\end{array}$} \\
\hline $\begin{array}{l}\text { 1.1.Tradition line of power and property: milieus of the } \\
\text { economic and state functional élites (c. 10\%) }\end{array}$ & $\begin{array}{l}\text { 1.1. The Conservative Technocratic Milieus } \\
\text { (.9\% - c. } 10 \%) \\
\text { (a) The Grand Bourgeois Milieu } \\
\text { (b) The Petty Bourgeois Milieu }\end{array}$ \\
\hline $\begin{array}{l}\text { 1.2. Tradition line of Higher Education and Services: } \\
\text { milieus of the humanist and service functional élites } \\
\text { (c. } 10 \%)\end{array}$ & $\begin{array}{l}\text { 1.2. The Liberal Intellectual Milieus } \\
\text { (c. } 9 \% \text { - c. } 10 \% \text { ) } \\
\text { (a) The Progressive Élite of Higher Learning } \\
\text { (b) The Milieu of the Higher Socio-Cultural Services }\end{array}$ \\
\hline 1.3. Tradition line of the cultural vanguard (c. $5 \%$ ) & $\begin{array}{l}\text { 1.3. The Alternative Milieu (c. } 5 \%-0 \%) \\
\text { The Post-modern Milieu (0\% - c. } 6 \% \text { ) }\end{array}$ \\
\hline \multicolumn{2}{|l|}{$\begin{array}{l}\text { 2. Milieus of the "respectable" popular and employee } \\
\text { classes [subdivisions corresponding to generations } \\
(a, b, c) \text { ] }\end{array}$} \\
\hline $\begin{array}{l}\text { 2.1.Tradition line of skilled work and practical } \\
\text { intelligence (c. } 30 \%)\end{array}$ & $\begin{array}{l}\text { 2.1.(a) The Traditional Working Class Milieu } \\
\text { (c. } 10 \% \text { - c. } 4 \% \text { ) } \\
\text { (b) The Meritocratic Employee Milieu (c. } 20 \% \text { - c. } 18 \% \text { ) } \\
\text { (c) The Modern Employee Milieu (0\%-c. } 8 \% \text { ) }\end{array}$ \\
\hline $\begin{array}{l}\text { 2.2. Tradition line of the petty bourgeois popular } \\
\text { classes } \\
\text { (between } 28 \% \text { and } 23 \% \text { ) }\end{array}$ & $\begin{array}{l}\text { 2.2.(a) The Petty Bourgeois Employee Milieu } \\
\text { (c. } 28 \% \text { - c. } 14 \% \text { ) } \\
\text { (b) The Modern Petty Bourgeois Employee Milieu } \\
(0 \% \text { - c. } 8 \%)\end{array}$ \\
\hline 2.3. Vanguard of youth culture (c. $10 \%$ ) & 2.3. The Hedonist Milieu (c. $10 \%$ - c. $12 \%$ ) \\
\hline $\begin{array}{l}\text { 3. Underprivileged popular classes (between } 8 \% \text { and } \\
13 \% \text { ) [subdivisions corresponding to orientation } \\
\text { towards the three 'respectable' popular milieus] }\end{array}$ & $\begin{array}{l}\text { 3.The Underprivileged Employee Milieus (a) The Status } \\
\text { Oriented (c. } 3 \% \text { ) } \\
\text { (b) The Fatalists (c. } 6 \% \text { ) } \\
\text { (c) The Hedonist Rebels (c. } 2 \% \text { ) }\end{array}$ \\
\hline
\end{tabular}

Figure 4 Tradition lines of class cultures (milieus) in West Germany

Note: The allocation of West German Milieus is based on our own representative Survey of 1991 (Vester et al., 1993, 2001). The percentage data concerning West Germany were taken from Sinus surveys (SPD, 1984, Becker et al., 1992, Flaig et al., 1993, 'Spiegel', 1996, stern, 2000).

delimits the petty bourgeois and conservative groups at the right margin. In the horizontal middle, we find the milieus for which work is the base of self-reliance and self-consciousness. At the left margin, the cleavage line of the vanguard separates the hedonistic or cultural vanguard with it's idealistic orientations, distinct from the balancing realism of the middle.

Finally, the axis of time is shown by the inner differentiation of the tradition lines. While Bourdieu (1992: 585-619) treated the popular classes in a rather short and summary way, we found this elaborate differentiation of the popular milieus. Each tradition line resembles a family tree, the younger branches mainly distinguishing themselves from the older by modernised cultural capital and 


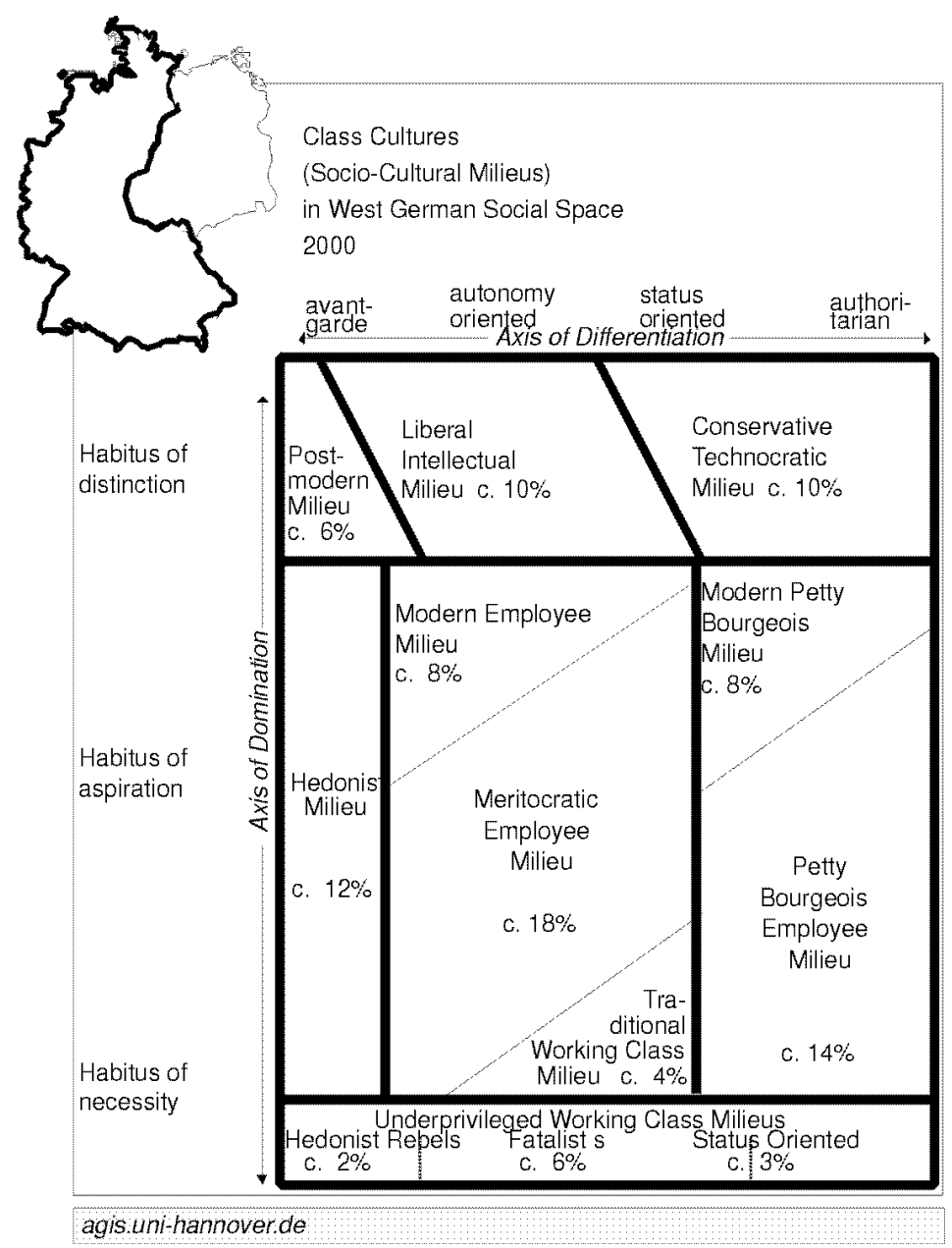

Figure 5 The map of West German Class Milieus

habitus. (As the younger branches are distinguished by modernized cultural capital and habitus, they are located a little higher and a little more to the left, symbolized by a thin diagonal distinction line.) Our synopsis (fig. 4) shows how this inner differentiation increased in a slow but constant movement, since 1982.

The presentation of the results of the 1991 representative survey could take advantage of the fact that the Sinus Institute continued to use the milieu indicator in it's surveys which allowed us to adapt our data on the macrological proportions up to the year of 2000 . The readers will notice that the changes are relatively modest - another support of the assumption that milieu change mainly is a long-term change by generations. 
The dominant class milieus: power, property and education

The upper social space is divided into five sub-milieus united culturally in their distinction from those who have little academic education and are less propertied and influential. This corresponds with their occupational concentration in the fields of the larger employers, of higher corporate and public management and of the professions.

At first sight, the dominant milieus as a whole remind of the "service class", as defined by Goldthorpe (1980). But Goldthorpe's employment aggregate approach which suggests a rather affirmative cultural homogeneity of the service class cannot differentiate the factions which lie at the roots of the dynamics of change in the upper milieus. ${ }^{9}$ Thus, it is certainly not true that the service class is united by the trust in the employer. Like the research of Savage et al. (1992) on the middle class, our empirical evidence in principle supports Bourdieu's identification of sub-groups as distinguished by their different strategies of social action. These factionings, which are essential for political and generational change, cannot be identified by the Goldthorpe approach, due to it's confinement to vertical differences.

On the horizontal axis, we could identify three formations which, in tendency, correspond to the differences found by Bourdieu and by Savage et al. The first two of these formations are the tradition lines of power and property and of higher learning and higher socio-cultural services.

In addition, inside each of the two lines we found an upper and a lower faction. These are somewhat similar to the findings of Herz (1990) who, in West Germany too, distinguished an upper and a lower service class by levels of competence. But there is more to these differences than occupational competence. Especially, the two upper groups play a culturally hegemonic role for the two lower groups. Their cultural and social capital has been handed on since many generations and is the highest in the society. The first of the two hegemonic groups follows the grand bourgeois tradition, the second group follows the tradition of humanist higher learning. The two lower groups are less endowed, the first being on the way downward, the second on the way upward. Below the "grand bourgeois" faction we find an aged "petty bourgeois" faction stemming from medium employers, civil servants and farmers with outdated endowments of cultural capital. Contrasting with this is the group we find below the humanist intellectual élite. It is a modern and relatively dynamic service élite, which made it's way upwards from the intellectual factions of the milieus of skilled workers and employees below them.

Analysing the West German service class according to the Goldthorpe approach, Thomas Herz (1990) started from mainly the same occupational groups as we arrived at. Consequently, the sizes are rather similar, i.e. between 20 and 23 per cent (Herz, 1990: 234) and between 18 and 20 per cent (Vögele, Bremer and Vester 2002, 275-309). However, Herz remains confined to the limits of the "employment aggregate" approach, which cannot give differentiated information on milieus as "action aggregates". He can give only wholesale information on the criteria of socio-cultural class cohesion, stating as common a high concentration of cultural capital, of privileges, of intergenerational continuity and of a common cultural identity. 
Concerning the career patterns, the Bourdieu criterion of "social capital" is very helpful to explain the dimensions of historical class reproduction and class reconversion as a whole. If we consider the specific dynamics to reach and to maintain occupational positions, this can be better specified by the asset approach of Savage et al. (1992) paying specific attention to the organisational resources and relations in the occupational world.

A third horizontal formation is found at the left margin of space. It is a milieu of the socio-cultural vanguard which is not simply to be explained by the same intergenerational accumulations of cultural, economic, social and/or organizational capital. As a cultural or political vanguard group, it is a result of the periodical secession from the core milieus of the top, waged by younger candidates for symbolic élite functions.

\section{The tradition line of power and property (1.1.)}

The tradition line of the Conservative-Technocratic Milieus (now about 10 per cent) is united by a habitus of an explicit sense of success, hierarchy and power, of a distinctive taste and of the exclusivity of their social circles and networks. They are the milieus of property and of institutional domination. To them belong the best-established parts of the employers, the professions, of the private and public managements and administrations, and of science and culture.

Since 1945, the old authoritarian capitalist, state and military upper class factions of Germany have lost their dominant positions to more modern and democratic younger factions legitimating their hegemony as an élite of merit, education and technocratic modernization and by cultivating a political discourse of "social partnership" with the employee classes, supporting the new historical compromise of the "institutionalized class conflict" (Geiger 1949, Dahrendorf 1957).

The dominant group follows the grand bourgeois tradition of erudite and tolerant conservatism. According to the data, it's members mainly consist of higher private and public managers, the owners of medium and big enterprises and members of the most privileged professions (especially in the medical and jurisprudence sectors). They belong to these groups at least in the third generation. This implies a long accumulation of social and cultural capital. Thus, the sub-milieu has one of the highest quotas of cultural capital: 37 per cent have Abitur (the secondary school diploma attesting the maturity to study at a university), 31 per cent have a university diploma.

In contrast, the dominated "petty bourgeois" faction of the milieu has surprisingly modest standards of cultural capital (very near to the survey averages of 13 percent for Abitur and of 5 per cent for the university diploma). Most of them completed their educational careers in professional schools and then enter the career ladders inside private or public managements. This pattern is connected with specific family traditions. The parents, too, had reached only average 
educational diplomas and, like the grandparents, were employers, civil servants and farmers of the medium level. This petty-bourgeois pattern of medium resources and sustained career efforts corresponds to a cultural tradition of a rather strict and less tolerant conservatism. The socio-historic explanation of these specifics is evident when we consider the age of the milieu members. Two thirds are over 65, the rest largely over 55 years of age (Wiebke, 2002: 304). This indicates that the group is largely identical with that faction of the bourgeois class, which was not able to join the reconversion towards or reinforcement of strategies of education which the majority of the bourgeois milieus made in the 1960s (see Bourdieu and Passeron, 1971) and consequently is leaving the historical stage, by and by.

Despite of these differences, the factions are united in their policies of "closure", rarely admitting newcomers and up-starts to their circles. These policies, in Germany, are implemented mainly by subtle habitus and cultural selection (Hartmann, 1998), working also as informal access barriers in the educational system.

The tradition line of higher education and higher services (1. 2.)

The second tradition line distinguishes itself exactly against this power conscious exclusiveness. It's milieus are not occupying the very "highest" but the "higher" ranks of administration and civil service, of the professions, the cultural, social and educational sectors and the arts. Being not at the very top, they tend to call themselves "middle class", while Bourdieu defines them as the "dominated faction of the dominating classes".

Opposing the "materialism" of it's rivals, the Liberal-Intellectual Milieu (about 10 per cent) prefers distinction in cultural terms, combined with the assertion that everybody could achieve higher intellectual standards if he or she only wanted. The milieu legitimates itself as an enlightened vanguard, responsible for the universalistic values of justice, peace and democracy and for the social and ecological problems caused by economic progress. Their claim of cultural hegemony over society is somewhat mediated by benevolent or caritative condescension. Moreover, there are differences between the two sub-groups of the milieu.

The dominating sub-group, the Progressive Elite of Higher Learning (about 5 per cent) is following older family traditions of humanist orientation. The grandparents already belonged to the well-educated upper stratum of mainly professionals, higher civil servants and self-employed. Today, they unite the majority of the academic intelligentsia in the occupations of natural and engineering as well as the social and cultural sciences, in the sectors of publishing, the media and advertising and in the pedagogical, psychological and therapeutical services. As already their grandparents, they have high standards of cultural capital, i.e. 41 per cent have an Abitur and 23 per cent have a university diploma. Their élitist progressism combines ascetic work ethics with an ethos of high 
professional performance and often with very distinctive cultural practices, expressive self-stylization and a sense for unconventional ways.

The dominated faction is the modernized Milieu of the Higher Socio-Cultural Services (about 4 per cent). It concentrates in higher administration (often connected with new information technologies), especially in public administration, financial departments and publishing sectors. Women, in addition to this, often work in advisory, medical-technical and educational occupations. The milieu's cultural capital is high only on the Abitur level (27 per cent) and lower in university diplomas (11 per cent) as, after school, most of them pass a professional school before starting a career in their occupation. Most of their parents and grandparents were skilled blue or white collar workers as well as small employers, i.e. mainly part of the tradition line of skilled work (2. 1.) with it's appreciation for education. Their way into the upper milieus was facilitated by the expansion of new qualified occupations in the economy and in the welfare state, after 1950. The heritage of the skilled workers' culture of modesty explains why this milieu keeps a certain distance to the expressive and distinctive self-stylization of the dominant faction.

\section{The tradition line of the cultural vanguard (1. 3.)}

In the early 1990s, the place of the vanguard milieu was still taken by the old Alternative Milieu characterized by the life-styles and ideals of the 1968 movements. It's members were mainly academic intellectuals working in the educational, research and cultural sectors as well as in the medical, therapeutical and social services, or preparing for these activities as students. They have a high rate of Abitur diplomas (28 per cent) and a rate of university diplomas which, with regard to the fact that many are still students, is also high (18 per cent).

Culturally, the group professed the post-materialist values of personal emancipation, individuality, authenticity as well as the universalistic or "class-less" values in the fields of gender, ethnicity, ecology, peace and participatory democracy. Since the early 1980's, when the respective movements succeeded to form the Green Party, the milieu had found increasing public acceptance. In turn, the "alternative" values were practiced in less "class-less" and increasingly realistic forms. Many former protesters had reached their tacit biographical aim to become part of the élites. In this process, the milieu, which in 1991 was already down to 2 per cent, was gradually re-absorbed by it's parent milieu, the progressive élite of higher learning.

Meanwhile, it's place has been taken by new and younger vanguard milieu, the Post-Modern Milieu (about 5 per cent). It combines esthetic vanguardism and a self-oriented ambition to get to the top of life-style, consumption and social positions. Mainly, it's members are up-starts, often younger than 35, with higher education and still living as singles. They are students or young academics working on a medium employee, profession or employer level, preferably in 
vanguard occupations of symbolic services, culture, the media, the new technologies, the arts and architecture, but also younger barristers, accountants and surveyors. (This composition is very near to the "postmoderns" found by Savage et al. and partly to the new petty bourgeoisie described by Bourdieu.) Meanwhile, the dreams of the new economy have given place to an increasing realism, and the milieu may well be re-absorbed by it's parent-milieus in order to be replaced by the next vanguard.

The respectable popular and employee classes

The difference of the Bourdieu and the milieu approaches, as compared to the employment aggregate approaches, is especially evident when we turn to the popular classes. Here, we find a horizontal differentiation between rather static and traditionalist milieus of employees (which largely consists of the offsprings of the former small owners), a group of rather dynamic employee milieus combining the search for education and autonomy with a sense of solidarity (being the offsprings of the former working class) and, finally, a vanguard of life-style (which mainly turns out to be a transitional stage of the children of the two other groups. $)^{10}$ It is important to note that, contrary to the ahistoric myth of proletarian collectivism, the key value of the new working or employee class is autonomy which it already was when the working class was made (Thompson, 1968, Vester, 1970) and which it also still is in Britain (Savage, 2000).

\section{Work orientation: the self-reliant labouring classes (2. 1.)}

An additional remarkable result, confirmed by our survey data, is that the milieus of the skilled working class, which historically formed the core of the labour movement, have not eroded in their numbers or habitus. They keep representing one third of the population (see fig. 4$)^{11}$ although they changed their appearance. Contrary to Beck and Giddens, taking part in the structural change towards more tertiary and white collar occupations did not mean giving up the basic dispositions of personal autonomy, ascetic work ethics and mutual help, though increasingly balanced by a moderate hedonism in the younger generations. Their main groups are the self-reliant and skilled blue and white-collar workers in modern occupations and a smaller faction of the small owners.

10 This is shown below, in the portrait of the woman who reconciled herself with work after a period of refusal.

11 Bismarck (1957) named the same percentage for the 1950s, and there are indications for a long historical duration of this quota. 
The value system is opposed to that of the petty bourgeois popular classes whose central value is social status, derived from hierarchical relations. Instead, for the milieus of skilled work and practical intelligence, autonomy is the central value, and it is primarily based on what a person can create independently, by his or her work and practice. This striking parallel to the diagnosis of Savage (2000) is well illustrated by the small portraits included in the text.

The other values are more or less derived from this. Education and culture are seen as an important means to develop personal competences of work, autonomy and orientation. Different personal achievements of work and learning may legitimate a certain differentiation or hierarchy in the social order. But this hierarchy of skills does not legitimate any class domination. Accordingly, "natural" or "power" inequalities as well as deference towards social, religious or political authorities are abhorred. Work orientation founds a meritocratic sense of equality. The value of a person should depend on the practical works, independent from gender, ethnic or class belongings.

\section{"all in your own responsibility"}

(A Traditional Worker)

Karl, aged 48, after secondary school and an apprenticeship as a carpenter, works at Volkswagen as a toolmaker. With his wife, a nurse, he lives in his own house in a small town. They have a son of 25. Karl's father was a carpenter, too, his mother was a housewife.

Going to Volkswagen was not only "the financial way" to fulfil his "youth's dream" to "build my own hut, here, " but also a struggle for autonomy at work. First working in a department with degrading work and "catastrophic emissions", he risked severe personal conflicts to be promoted to his present working place which is "rather good", "a surrounding (of workmates) that fits": "You work independently, one is allowed to decide by oneself how it is done and so, is all in your own responsibility."

In his leisure time, Karl is rather active, as a hobby photographer, going to the theatre, doing carpenter work in his house, acquiring his yachting certificate. He meets his friends for card playing but does not like to be a club person: "I'd rather be independent". However, this does not limit his political activity, in the trade union and also the Social Democratic Party where he contributes to a magazine being challenged to activate his talents to write: "These are things to keep you going, mentally, in order to have something different, a very different metier. " Karl actively participates in the courses of workers' education, distinguishing himself from the young frustrated workers "interested in nothing", with their "assembly line faces". He likes the courses to be well organized and socially useful, e.g. relating his hobby photographing with the presentation of societal problems.

Meanwhile, Karl says, "I have got myself everything I wanted to have" (a house, a sailing boat, a computer etc.), but always caring that "I really earned it, first". At the sametime, he is severely worried about the unemployment of his son and his wife: "There, I don't have a perspective. " Although active in labour politics, he is critical: the trade union is "too much a closed bunch, blocking unfamiliar ideas". (Bremer, 1999: 104-106)

Solidarity is not a value in itself but a necessary condition of personal autonomy which is thought to be dependent on mutual help and co-operation. It does not mean collectivism but is following the older tradition of neigbourly help and emergency ethics (Weber, 1964), which, is manifestly mobilized only on special occasions and for special cases. If somebody is in distress without being 
personally responsible for it, help is the neighbours' duty. This principle is also transferred to the political field. The welfare state should not support any feather-bedding. But it should help everybody who is in need without being responsible for this situation.

Work and life style are largely structured by a special variant of Weberian "protestant ethic", a rational and realistic method of conducing life. In this variant, however, work and self-discipline again are not values in themselves, which lead to the proverbial puritan morosity, but combined with the conviction to be entitled to enjoy the fruits of the own and common efforts and to receive social justice.

This general value pattern may articulate in many different ways, according to the field situation. In situations of declassment and humiliation it may motivate militant collective action. In a situation of occupational change it may motivate reconversions for new occupational fields by strong educational efforts on a family level. In a situation of prosperity, personal acquisition may come to the fore. Historically, the habitus pattern itself may shift the balance of it's different traits as new generations with new formative experiences are developing their own ways. - Our data permit to distinguish three milieus each of which is mainly centered around a different age cohort.

"that I reconciled myself with work"

(A Meritocratic and Former Hedonist Employee)

Christiane is aged 43. As her mother, she is an employee in public administration, while her father is an engineer. After secondary school she "hanged around at schools for quite some time", before her parents ("now it is enough") made her go to a training for an office occupation. However, she started her professional career only after the five years of her first marriage, when she was alone with her little son. Now, she lives together with her second husband, a dental technician, and her son.

"Interest in my occupation has grown by and by as years passed" and as family obligations became less absorbing. She acquired additional education and a more interesting post in her office. However: "It could be a little more responsibility". Consequently she put up with the additional strain and costs of a correspondence course to prepare for a further advancement. At her age, she is "glad to have found my warm place, that I reconciled myself with work and even find it interesting". The pragmatic orientation of usefulness is also valid for her interest in adult education. She prefers purposeful programmes, not "chatting clubs ... where everybody tells what he is doing and possibly returns home as stupid as he came". She wants to "get something into her hand", while the surrounding does not have to be luxurious.

This all leaves her little time for her leisure activities (photographing, movies, museums and exhibitions), which she shares with her husband. "Material things should not be put to the front" although they are not unimportant. Most important, however, is the reliability of social relations for which "you have to do something — not only making use of it unilaterally ... We have lived to be there for others. " Her present husband is a good and equalitarian partner, still interesting after 12 years, despite different opinions on education.

Political education is important to be informed and to understand articles in the press. But: "You can read much, but it is better to discuss it with others. " As already her mother, she is active in the works council, without considering this as "political". Trade unions are "indispensable as representatives of the interests of the employees", but their structures have become too rigid and immobile. Therefore, she would not become a trade union militant: "I would probably be fed up, soon"

(Bremer, 1999: 128-130). 
The Traditional Working Class Milieu, a sort of "grandparent generation", is still identified with the necessities of physical work and scarcity. In West Germany, it melted down to about four per cent. Here, the distance to the powerful is felt most while the relations with friends, work mates and neighbours are still highly valued in the sense of the old working class culture. The old "proletarian experience" of want, of insecure and limited incomes and of more traditional work skills is still remembered. At work, the milieu members follow the disciplined ethos of good, responsible skilled work. At home and in consumption, they modestly adapt to the necessary. Participation in social standards has to be earned by one's own work.

The "parent generation" already grew up during the economic growth decades since the 50s, with the experience of rising social rights and standards. They grew to a new milieu of about 20 per cent which Goldthorpe and Lockwood called the Affluent Workers ${ }^{12}$ and which we might call the Meritocratic Employee Milieu - as they strongly believe in hard skilled work which, then, legitimates participating in the standards of consumption, leisure and social security of the welfare society. Their skills, education and social standards are better than those of the grandparent generation, but not extravagant. Their occupations are those of modern employees, the men mainly in skilled blue-collar work, the women mainly in skilled white-collar work.

The generation of the "grand children" mainly grew up since the end 60s, in the context of educational reforms, new work and communication technologies, new social movements and a wider variety of life styles. This Modern Employee Milieu, first described around $1990,{ }^{13}$ is growing rapidly, yet comprising more than eight per cent. They are "individualized", however in the sense of a strong sense of personal autonomy and competence which, at the same time, is balanced with a rather high level of social cohesiveness, responsibility and employee-consciousness.

The milieu reminds of the old cosmopolitan culture of the curious and creative artisan, with his passion for learning and wandering. They work in the most modern branches of technical, social, and organizational work, in academically specialized practical occupations, ready to learn new arts and languages, and convinced of the necessity of good skilled work - and of participating in the decisions at work as well as in politics. However, this work ethic does not operate as an incentive for endless careers and acquisition. It is, in their time schedules, balanced by a caring for their friends, neighbours and parents. Although horizontal solidarity did not disappear, their autonomous habitus makes them difficult members of trade unions and other organizations with a rigid hierarchical style. However, their openness for non-conventional life styles differs from that of the "hedonistic milieu" described later because they

12 Strictly speaking, Goldthorpe et al (1968) studied a specific group of "affluent workers", i.e. those in de-skilled work and urban living conditions, which is only in part identical with the milieu described here. For a detailed discussion see Vester, 1998.

13 This type was first explored by mentality researchers in Hannover (Mueller, 1990; Vester, 1992), Heidelberg (Flaig et al., 1993) and Göttingen (Baethge, 1991). 
share the sceptical employee realism of the older milieus of their family tree. Hedonism and personal emancipation are adapted to the frame of the possible.

In all three generations of milieus, trade union affiliation is still substantial although gradually weakened: around 32 in the grand-parent milieu, around 28 in the parent milieu and 24 in the youngest milieu. In their majority, all three milieus are highly disappointed by the neoliberal tendencies in the political parties.

"not to do always the same thing"

(A Modern Employee)

Sabine, aged 31, is a dental technician, living with her mother, a cleaning lady living separated from her father, a painter.

After Abitur, she became dental technician "because I am a tinkering soul". She went to a small firm where "I can organize my work independently" and work is not monotonous: "For me it is tremendously important not to do always the same thing. "Studying is not her way as she likes "to have a result on the table", "something useful and meaningful". "Money was not that important for $m e^{\prime \prime}$. However, she dislikes the increasing stress on the job.

Sabine is a committed trade unionist, member of the works council and often with a full schedule all the week. Therefore she needs distance from work in the rest of her time. She likes to read or "let the soul dangle" in the garden of her boyfriend (a full-time works council member) or to make walking tours with the Friends of Nature, a labour youth organization. For her, as an active and interested person, beach vacations are "boring". Similarly, she likes educational courses, organized not like school teaching but in a modern and inspiring way, on an equal footing. The surrounding does not have to be luxurious.

Politics often don't meet her demands, being connected "much with lulling" and "redundancy" and with annoying forms of conflicts. But: "If you want to move something you must commit yourself" (Bremer, 1999: 119-120).

\section{Hierarchic orientation: the petty bourgeois labouring classes (2. 2.)}

The second tradition line of the "respectable" popular milieus goes back to the old deferent popular classes living in narrow, hierarchical conditions. Today, it unites small employees and owners in traditional occupations. With their modest material and educational resources, they are likely to be the losers of economic modernization. They are looking for security in the hierarchies and duties of work, politics and the family. This corresponds with a conventional and authoritarian habitus. Solidarity is mainly limited to the core family - and combined with the hierarchical loyalty between patrons and clients.

However, outspoken authoritarianism has somewhat been modified by modern life styles. The classical Petty Bourgeois Employee Milieu, which had 28 per cent in 1982, lost 14 percent who now are mainly to be found in the Modern Petty Bourgeois Employee Milieu of eight percent. This younger milieu has more solid occupational qualifications and incomes and can modernize the petty bourgeois life style by elements of individual hedonism and of modern comfort. It 
can satisfy it's striving for security better than the parent milieu, balancing authoritarianism by tolerant styles. But the fundamental belief in occupational, familial and ethnic hierarchies is still dominating.

Politically, both milieus have strong conservative and partly rightist leanings. However, up to now four fifths of them give their votes to the big conservative or social-democratic parties, still viewing them as a more reliable guarantee of security interests. Parts of the milieus are important for labour. They are the "authoritarian workers" who are a membership group trade unions have to count with. Trade union membership is around the average ( 20 per cent in the older, 26 per cent in the younger milieu). The conservative pattern of patron and client does not mean unconditional obedience. It also implies that the patron has duties, which he can be reminded of. Of course, this disposition will be articulated differently, depending on field conditions. When there is strong fear of declassment - and disenchantment concerning the employee society, significant minorities of the milieu might turn to reactionary or racist resentments, today especially rightist populism.

\section{Life style orientation: the hedonist popular classes (2. 3.)}

On the left margin of the middle, we see a formation, which defines itself as a sort of vanguard of life style. The members of the Hedonist Milieu (12 per cent) profess conspicuous anti-conformism, individual autonomy and spontaneous enjoyment of the exciting possibilities of modern life style and consumption. These peculiarities rarely are seen as a proof of the dissolution of traditional class cultures. Indeed, they reject the petty bourgeois habitus of duty and order as well as the skilled employees' work orientation and self-discipline.

This delimitation may be interpreted differently when we consider the data. The milieu mainly consists of young people under thirty whose parents and grand parents belong to the occupational groups of the "respectable" tradition lines. The rejection of conventional values, then, may also be seen as part of the generational conflict with their parents who are belonging either to the petty bourgeois or to the skill oriented tradition lines. The strong negative identification disguises the internal differences of the young hedonists, The milieu is a transitory formation constituted by the prolonged adolescent rebellion against the narrow perspectives of necessity, harmony, security and thrift.

At the same time, our data show that about four fifths of the milieu comply to the usual everyday routines of school, work and social obligations, and about one fifth professes to go to church on Sunday mornings. Thus, for most milieu members' hedonism means little more than a leisure time compensation.

Moreover, since the golden years are over, hedonism has got into difficulties. According to their age, many milieu members did not yet leave the phases of education and transitional jobs behind them. Others are in the situation of low qualified blue and white-collar work or unemployment. Thus, medium and small 
incomes are the rule, and hedonism touches it's material limits so that the group is segregated into winners and loosers.

Especially, the thesis of eroding trade union affiliations is not supported by our data. The percentage of trade union membership is about 26 in the whole milieu, 30 for men and 22 for women. This, again, is around the average of the popular classes.

\section{Orientations of powerlessness: the underprivileged popular classes}

The third main group of the popular and employee classes differs from the two "respectable" traditions lines above them which, in "normal times", enjoy an integrated economic and moral status. The third tradition line, instead, is not stably integrated into this nexus of giving and taking and the respective traditions of internalized social control, thus seemingly justifying it's "underclass" position below the invisible border line of respectability.

However, the underclass of the Underprivileged Working Class Milieus, about 12 per cent, is not different in all respects. Like the self-reliant labouring classes they give high priority to their family, friends and peers. But they differ in the means. For them, work is not "fulfilment" (as it is for the self-reliant milieus) or a "duty" (as it is for the petty-bourgeois milieus). It is a necessary burden, especially as they mostly occupy the less skilled, less secure and less paid jobs.

For them, the world is deeply divided into the powerful and the underdogs. Intellectuals often misunderstand this polarized power image of society as a source of clear proletarian class-consciousness and militancy. Empirically, however, their confidence in their own forces is realistically limited. With little own resources of economic and cultural capital, the future of their employment and well-being is insecure. Being very conscious of the risks to be destabilized and stigmatized, they prefer to develop strategies of flexibility and of keeping up with the standards of the well-to-do classes and of leaning on to stronger actors - the trade unions, the boss, a good marriage or lucky occasions of many kinds. In this, they follow the old tradition of the pre-industrial underclasses. With them, they share the belief that investment in personal relations (horizontally as well a vertically) is most important for social recognition while educational achievements or legal equality cannot be trusted.

These strategies vary, according to the three sub-milieus they belong to. The Fatalist sub-milieu (about 6 per cent) sticks to the underdog philosophy that all personal efforts are futile. But they see the trade unions as their voice and almost one third of them are trade union members. The same is true for the Status-Oriented sub-milieu (about 3 per cent) although it is not so "progressive" in other respects. It's members adopt the petty-bourgeois strategies of conformity with patriarchalism in the family, discipline and reliability on the job and conventionalism of life style. Instead, the Hedonist Rebels (about 2 per cent) follow 
the libertarian philosophy of the hedonistic milieu, practicing distance towards the authorities of the state, the churches, higher education, patriarchalism etc. Although this is the most "individualized" of the three sub-milieus, it's trade union affiliation is the strongest: 44 per cent.

"I live through the day, seeing what comes."

(An Underprivileged Worker)

Kalle, a Volkswagen worker of 28, still lives in the house of his parents, constructed through hard work. His father was an unskilled worker who is now pensioned after unemployment, his mother is a housewife.

After primary school, an apprenticeship as a motor mechanic and a period of changing jobs, he went to Volkswagen. "The step into the factory was the money". Here, too, he changed the department several times because of conflicts with the foremen. He is not content to work in a material supply department: "you feel like a hen in a big factory". But he does not see a way out. To make his master craftsman's diploma is too risky: "It costs 10. 000 Marks. " And: "Without influential relations you don't have a chance".

In his leisure time, Kalle mainly wants to have fun, meeting friends in a pub or discotheque, motorbiking or drinking. He likes to be independent, with "no big obligations". "I live through the day, seeing what comes. I enjoy simply, I cannot make big plans. " He does not want "to work all my life" and dreams of a "winning lotto ticket" to buy a house, "in Canada or Australia or everywhere".

He takes advantage of his right of an annual workers' education course, mainly to get off the job and "to meet other people". It is important to "talk a little", with a beer. He likes people who "like big talking" and not those who "come with a briefcase, sit down and swot. " However, in the courses, "a little education is okay".

Politics is not one of Kalle's hobbies. Politicians are much alike, thinking "how they can best fleece the little man. " The results of politics are best seen "in my wage packet". Talking politics "is no use" (Bremer, 1999: 110-111).

Our data show that the strategies of leaning-on of most of the underprivileged workers were partly successful although they did mainly not participate in the educational revolution since the 60s (Geißler, 1994). Their school achievements are still low although more stable. However, the post-war Fordist model of social integration allowed them rather secure low-skill jobs in the pits, on the railway, in the supermarkets or the assembly lines of big industry and also rather stable incomes. But this model is now eroding, as the less skilled jobs are exported to cheap labour countries and the social guarantees of the welfare state are increasingly reduced. Today, the underprivileged blue and white-collar workers are dividing into several parts. Many now are among the main losers of modernization, forming the largest portion of the permanently unemployed. Others return to the old milieu strategies of combining small jobs and opportunities and of activating their networks in the informal economy. Politically, parts of the milieus may also enter into actions against ethnic minorities or into right wing populist protest. 


\section{Ideological camps and the problem of societal integration}

The political consequences of the present social destabilizations bring us back to the question of political class-consciousness. Without claiming to go deeper into cleavage research, I shall discuss the ideological camp cleavages we found in our representative survey in connection with the problem whether voting preferences can be deduced from class, as defined by employment aggregates or by milieus.

One of the prominent theses, discussed also by Crompton (1998: 86-89), is that the link between being a worker and leftist voting have become increasingly tenuous. Following the lines of Offe (1985), Beck and Giddens have developed the "new political model" supposing a tendency that the values of material redistribution of class society would erode in favour of post-materialist values beyond class cleavages.

In our study, we had already found that, contrary to these theories, on the level of everyday culture, the class differences of life-style and habitus are still persisting, though in modernized forms. However, we did not assume that everyday class culture necessarily translates directly into socio-political or ideological cleavages, in the political field.

To test this in our representative survey, we used a special indicator of 45 statements concerning basic attitudes towards social justice and politics (Vester et al., 2001: 550-552). Submitting the results to cluster and factor analyses, we could validate a cluster solution, which showed that there were six camps adhering to distinct concepts of social justice and models of the socio-political order. For each camp, detailed statistical and attitude profiles could be formulated (ib.: 444-472).

In a second step, we took our map of class milieus (fig. 5) and located these six camps in it, according to their distribution over the milieus. The resulting new map (fig. 6) shows that there is no new camp beyond class cleavages. Each camp has a specific location in social space. However, each camp crosses milieu borders, as it forms a sort of coalition between factions of different milieus. As already developed above (in the fifth paragraph of this article), this is nothing new. Historical research on camp cleavages confirms that, due to the logic of the political field, this is the normal case (Lepsius, 1973, see also Hall and Jefferson, 1977). In this context, Beck and Giddens had not been realistic assuming that political cleavages ever followed vertical class divisions.

However, we could find the new camp described by them. It is the camp of the Radical Democrats, adhering indeed to the named universalistic and seemingly "class-less" values of civil society and ecology, of gender and ethnic emancipation etc. However, it had only 11 per cent, and a new representative survey of the year 2000 confirms no significant expansion (Vester, 2001). Our data also indicate why the camp did find only very limited support below the upper class milieus. The reason lies in an élitist ideology justifying the own position near the top by the virtues of a puritan work ethic, which allegedly is lacking in the lower milieus. None of the other camps shows such an affinity to the unpopular neo-liberal politics. 


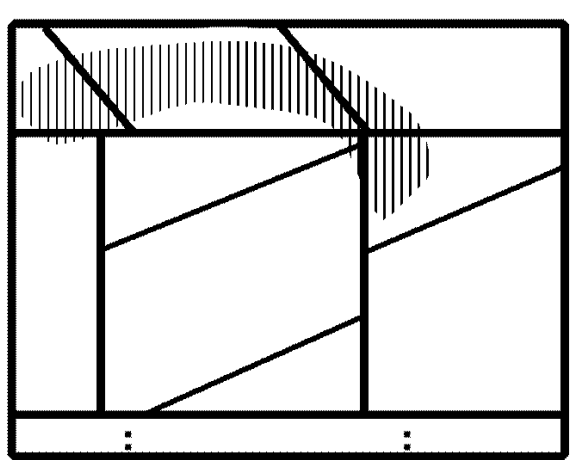

Radical Democrat Camp (c. 11\%)

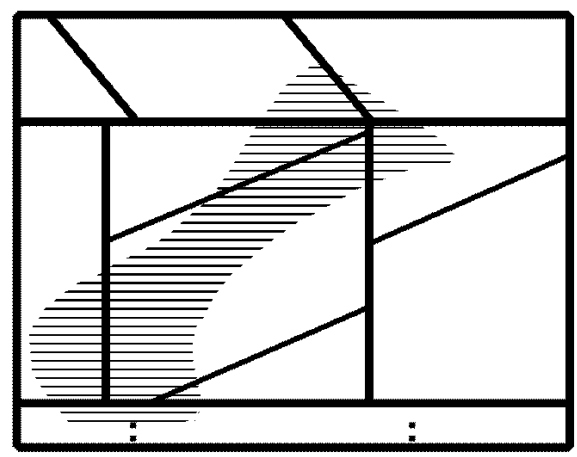

Camp of Social Integration(c. $13 \%$ )

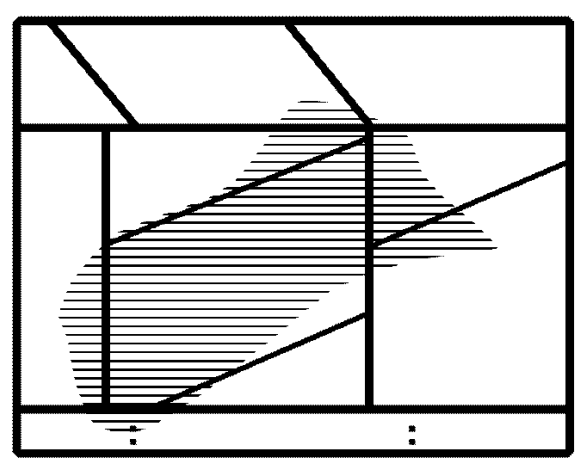

Camp of Sceptical Distance (c. 18\%)

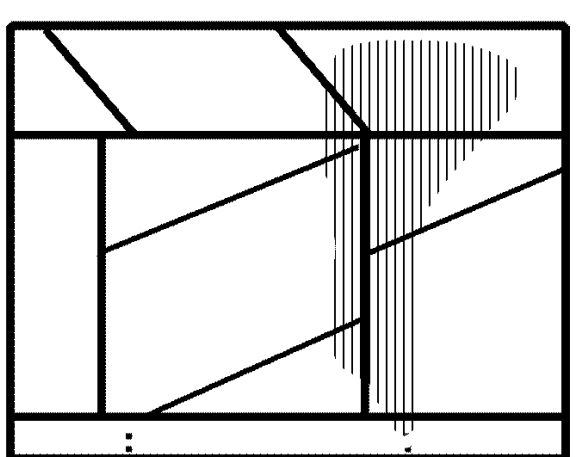

Traditionalist Conservative Camp (c. 14\%)

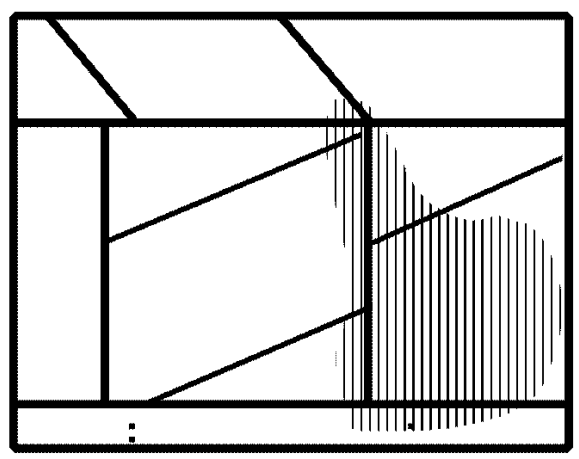

Conservative Employee Camp (c. 18\%)

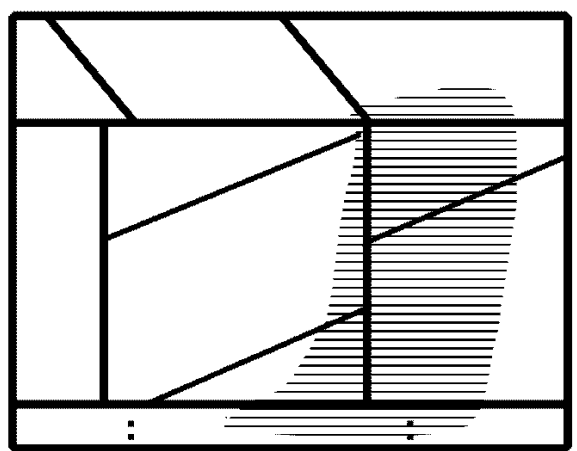

Camp of the Frustrated Authoritarians (c. $27 \%$ )

agis uni-hannover.de

Figure 6 The socio-political camps in social space 
Interestingly enough, there is one camp, which exactly shares the values of the Radical Democrats - but combines them with the values of universal social inclusion, aiming not only at gender and ethnic integration but also at the integration of the employee classes and the socially disadvantaged. This camp of Social Integration (about 13 per cent) is largely based on a modern reform intelligentsia, which is well represented not only at the top but also in the middle and lower milieu levels. Thus, it is very near to the camp of Sceptical Distance (about 18 per cent) which has it's main base in the skilled employee classes and favours a solidarity model of reciprocity. Who contributes to productivity and the welfare state (and those in undeserved misery) should also participate in their benefits. Their distrust in party politics is based on the view that there is too little social justice for the ordinary people in the present economic transition.

Another, more hierarchic model of solidarity is favoured by the Conservative Employee Camp, with it's strongholds among the petty bourgeois blue and white collar workers. Believing in a clientelistic model, where loyalty is repaid by benevolent paternalistic care, they mainly adhere to the christian-democratic party or the right wing of social democracy. However, one third of this 18 per cent group have turned to modern life-styles and demand a more tolerant style from politics, based on a more equal footing. This may translate into a change from conservative to social democratic voting. This exerts pressure on the Traditionalist Conservative Camp (c. 14 per cent) which, in social space, takes the patron's position above the "conservative employees". Their conservatism implies a rather rigid respect for the hierarchies of status although no social group shall be totally excluded.

However, this did already happen at the right and lower margins of social space where we find older and partly younger milieus with little educational capital and insecure future perspectives. This Camp of the Frustrated Authoritarians unites those losers of economic modernization who are interpreting their situation according to authoritarian habitus patterns. They feel excluded by the rest of society and compensate this by resentments against foreigners, everything modern and also the politicians who neglect their duties. Against the risks of social transformation, they plea for a protectionist state which keeps away competitors from the world market as well as from other ethnicities. Up to now, members of this 27 per cent camp are mostly seeking this protection from the christian democratic or the social democratic parties. But regional elections, as in Hamburg, already showed that they might turn to right wing populist voting up to 18 per cent.

Does this panorama of ideological camps mean that society is torn apart by different interests which can no more be bound together by an integrative formula as formerly was the welfare state? - This highly depends on the politics of the political élites. First, our survey showed that the old German welfare state model is still basically accepted by a majority of about eighty per cent. Second, a comparison of the six concepts of social-political order shows that they could be led together by their common denominator.

The models of solidarity are prevailing with 49 per cent. These are models where solidarity and personal responsibility belong together and should not be played off against each other, as it is the case in the two extreme social models of 


\begin{tabular}{|c|c|}
\hline Ideological camps and socio-political models in Germany & $\%$ \\
\hline $\begin{array}{l}\text { Élite models (c. } \mathbf{2 5 \%} \text { ) } \\
\text { (1) Radical Democrat Camp: progressive-liberal élite model } \\
\text { (2) Traditionalist Conservative Camp: paternalist conservative model }\end{array}$ & $\begin{array}{l}\text { c. } 11 \\
\text { c. } 14\end{array}$ \\
\hline $\begin{array}{l}\text { Models of Solidarity (c. } \mathbf{4 9 \% )} \\
\text { (3) Conservative Employee Camp: conservative model of solidarity } \\
\text { (4) Camp of Social Integration: progressive model of solidarity } \\
\text { (5) Camp of Sceptical Distance: model of mutuality }\end{array}$ & $\begin{array}{l}\text { c. } 18 \\
\text { c. } 13 \\
\text { c. } 18\end{array}$ \\
\hline $\begin{array}{l}\text { Protectionist models (c. } \mathbf{2 7 \%} \text { ) } \\
\text { (6) Camp of the Frustrated Authoritarians: populist model of protection }\end{array}$ & c. 27 \\
\hline
\end{tabular}

Figure 7 Ideological camps and socio-political models in Germany

Note: $n=2$. 684; German speaking residential population of 14 years and older in private households; cluster and factor analyses.

Font: Representative survey Socio-Political Milieus in West Germany, 1991 (Vester et al., 2001, chapter 12).

protectionism and of neo-liberalism. The two elements - solidarity and personal responsibility - could be united in the new integrating concept of a "participatory welfare state" (Vester, 2001: 172-180). This formula could be administrated by a government under social democratic as well as under conservative priorities. The large minority of the authoritarian losers, which support a protectionist model, could be lured away from populism by a policy of social minimum guarantees. The small minority of the Radical Democrats which socially is on the winner side could be attracted by a participatory remodeling of the welfare state. Despite of these integrative formulae there will still remain considerable conflicts, especially concerning the health and social insurance systems, the problem of precarious labour and the opening of the educational system for the less privileged.

\section{Conclusions}

Going back to the initial questions, I can conclude that the transnational application of the Bourdieu approach did not only show the limits of Bourdieu's analysis of the French class society. It also stimulated, by combination with the discourses in other countries, further developments enlarging the possibilities of this approach. These developments were also helpful to tackle the problems which could not be solved by the employment aggregate and the individualisation approaches to class analysis.

The research inspired by Bourdieu, especially Lamont (1992), Savage et al. (1992) and Rupp (1995 and 1997) as well as our own work (Vester et al., 1993, 2001), did not only show that in the middle classes and also in the employee classes there is a structured differentiation of class factions and their cultures. Insisting on the 
specific weight and dynamics of culture, it also points to new analytical distinctions by which the paradoxes and inconsistencies of conventional class concepts might be brought nearer to their solution.

This encourages a new sight on the second problem, the seemingly static consequences of Bourdieu's theory as long it was only applicated to the French society of the 70s. Indeed, the changes and shifts in social structure as a whole can be understood better when culture is understood not only in it's use as an instrument of symbolic domination used by the privileged classes, but also as a movement of social innovation and possible change on the horizontal axis of social space. The introduction of this axis, in combination with the axis of time, may turn out as one of the most consequential innovations of Bourdieu's work.

This is implied in two empirical observations. First, while in the upper echelons of society the drift towards more cultural capital and generational change may mainly serve the reproduction of class domination, the authors (Lamont, Savage et al., 1992; Vester et al., 2001) also discovered middle class factions with "indistinctive" cultural patterns, which may be possibly open for more participatory tendencies from below. Understanding the upper milieus as a dynamic field of forces helps to understand social change better than the rather static and affirmative concept of a service class. Second, the increase of cultural capital in the popular milieus also strengthens their position in the struggles for more participation in social chances and decisions. In other words, the movement of classes to the left pole of social space constitutes a contradictory development. On the one hand, classes and class society are not dissolved but on a horizontal movement which, by itself, does not change vertical structures of domination. On the other hand, while class domination remains, at the same time the potentials for social and political emancipation, which may challenge this domination, are growing.

This is the true element in the theories of individualization, post-materialism, affluence, the rise of classlessness etc. But while these theories are more or less supposing that these tendencies are subject-less and one-dimensional processes, the Bourdieu approach may explain, that these phenomena have their function and meaning in a different context, constituting a new constellation of social conflicts, strengthening the counter-powers of all who participate in the increase of cultural capital and the sense of autonomy: not only the employed classes but also the gender, age and ethnic dominated groups.

Finally, the dynamic use of the Bourdieu approach may also help to solve some of the methodological paradoxes inherent in the conventions defining classes by mere employment aggregates or human action by mere economic interest. Three of these possible solutions are especially noteworthy.

First, when class-belonging is based on a common habitus and on common biographical strategies transmitted mainly in the families and milieus, it is also connected with the preference for specific zones in the occupational field - but not deduced from it. Also already Schumpeter (1927) noted in his famous study on the European aristocracy, Classes may reconvert to new economic bases through crises, but mainly without losing their basic cohesion and identity. This also explains their survival by the habitus metamorphoses, which are the base of class family trees. 
Second, when class belonging is based on habitus, the discussion whether the belonging of women is given by their occupation or by their husbands turns out to be one of the "pseudo-discussions", exposed by Rosemary Crompton (1998).

Third, the rediscovery of the known fact that political attitudes are not part of the everyday level of class culture but part of the special ideological and/or intellectual levels of society may make clear that it never could be expected that there was a direct, untorted relation between occupational class and voting. Turning back to Bourdieu's Distinction, we may discover his map of political space as characterized by a "systematic tortion". Empirically, however, this "tortion" is not to be explained by one structural principle but by the political, ideological and religious struggles and coalitions of the historical past which are conserved in the institutional, attitudinal and mental traditions as forces with an own, perpetuing weight.

The difficult task to integrate complex societies cannot be tackled by organizing policies around supposed single trends, mechanisms or dominant groups as theories of post-materialism, of individualization or of the service class tried to recommend. If Ralf Dahrendorf's vision of the coming of a new authoritarian century shall be disproved a better knowledge of societal dynamics is needed, including theories and an empirical diagnoses which allow to distinguish the dimensions of complex societies by a new approach which differentiates as well as integrates these dimensions. 


\section{Annexes}

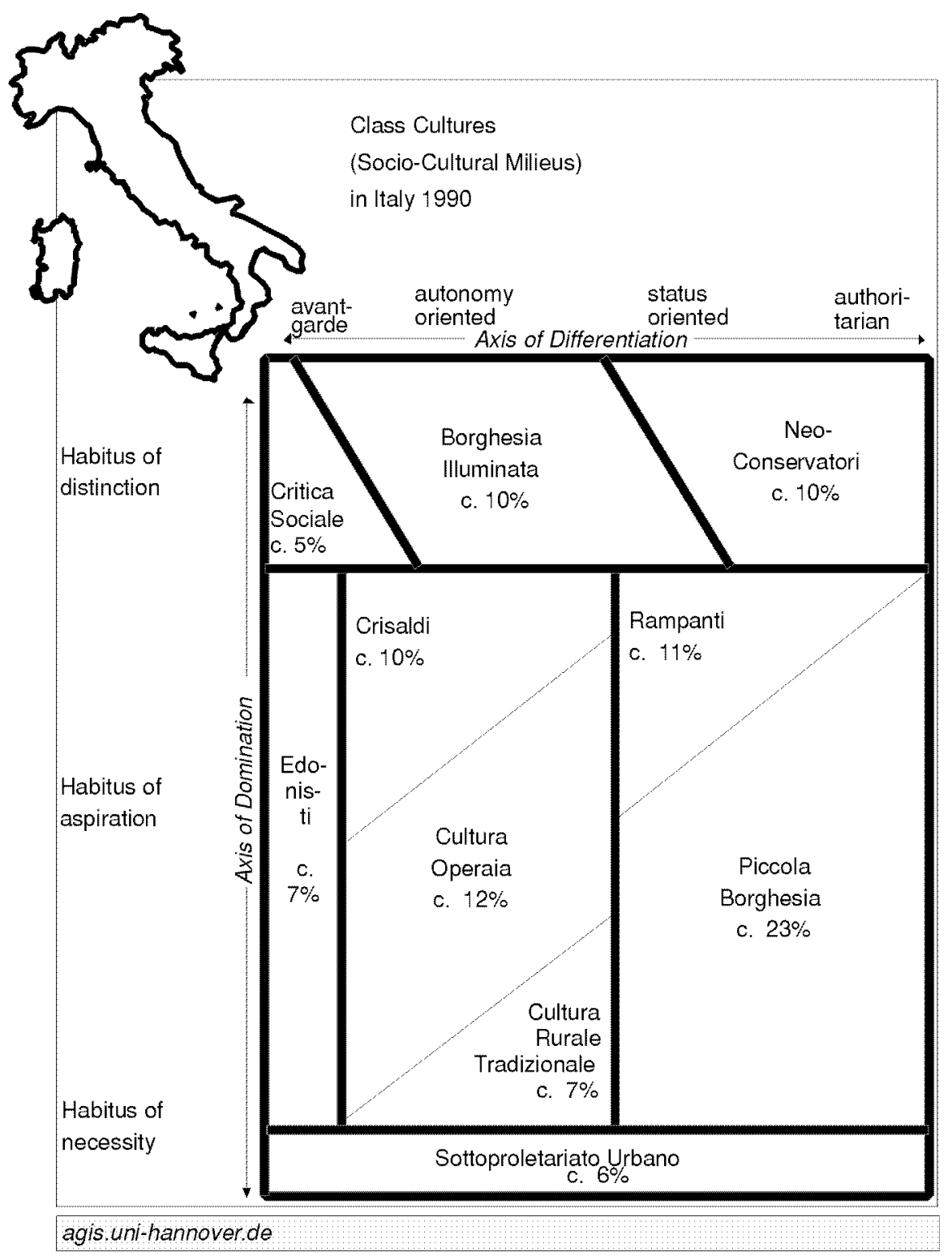

Figure A1 The map of Italy Class Milieus 


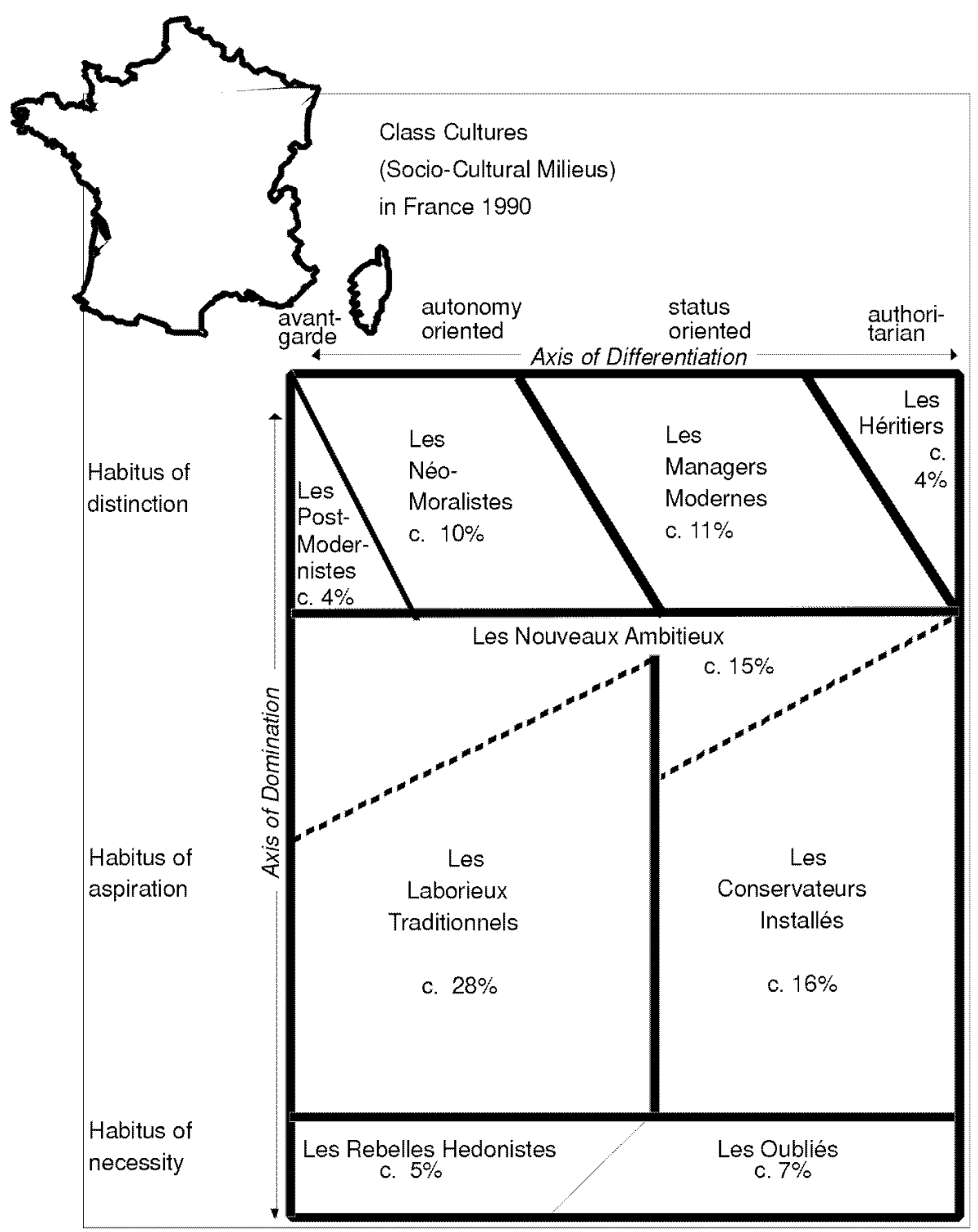

agis uni hannoverde

Figure A2 The map of France Class Milieus 


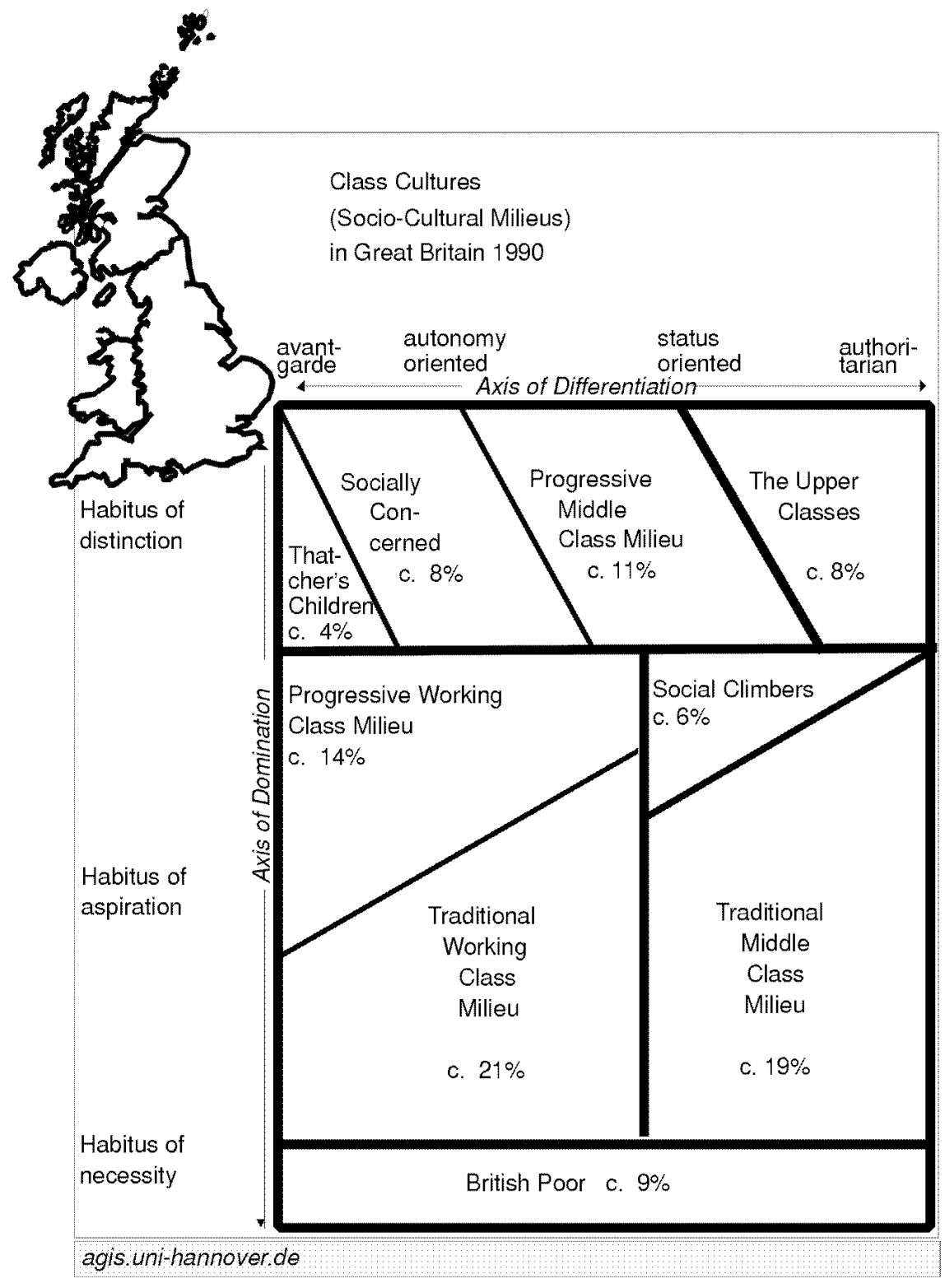

Figure A3 The map of Great Britan Class Milieus 


\section{Bibliography}

Baethge, Martin (1991), “Arbeit, Vergesellschaftung, Identität: zur zunehmenden subjektivierung der arbeit", in Zapf, Wolfgang (ed.) Die Modernisierung Moderner Gesellschaften, Frankfurt/Main, New York: Campus, pp. 260-278.

Becker, Ulrich, Horst Becker, Walter Ruhland (1992), Zwischen Angst und Aufbruch: Das Lebensgefühl der Deutschen in Ost und West nach der Wiedervereinigung, Duesseldorf, Econ.

Bell, Daniel (1973), The Coming of Post-Intustrial Society. A Venture in Social Forecasting, New York, Basis Books.

von Bismarck, Klaus (1957), "Kirche und Gemeinde in soziologischer sicht", Zeitschrift für Evangelische Ethik, H. 1, pp. 17-31.

Bourdieu, Pierre $(1979,1992)$, Distinction: A Social Critique of the Judgement of Taste, London, Routledge \& Kegan Paul.

Bourdieu, Pierre, and Jean-Claude Passeron (1971), Die Illusion der Chancengleichheit, Stuttgart, Klett.

Bremer, Helmut (1999), Soziale Milieus und Bildungsurlaub, Hannover, Agis Texte.

Crompton, Rosemary (1998), Class and Stratification, Cambridge, Polity, 2nd edn.

Dahrendorf, Ralf (1957), Soziale Klassen und Klassenkonflikt in der industriellen Gesellschaft, Stuttgart, Enke (Class and Class Conflict in an Industrial Society, London, Routledge, 1959).

Devine, Fiona, Mike Savage, John Scott, andRosemary Crompton (eds.) (forth coming), Rethinking Class: Cultures, Identities and Life-Styles, London.

Durkheim, Émile (1894, 1961), Die Regeln der Soziologischen Methode, Neuwied, Luchterhand.

Durkheim, Émile (1893, 1902, 1988), Ueber Soziale Arbeitsteilung, Frankfurt, a. M.

Flaig, Berthold Bodo, Thomas Meyer, and Jörg Ueltzhoeffer (1993), Alltagsästhetik und Politische Kultur, Bonn, J. H. W. Dietz Nachf.

Geißler, Rainer (ed.) (1994), Soziale Schichtung und Lebenschancen in Deutschland, Stuttgart, Enke.

Geiger, Theodor (1932), Die Soziale Schichtung des deutschen Volkes, Stuttgart, Enke.

Geiger, Theodor (1949), Die Klassengesellschaft im Schmelztiegel, Köln und Hagen, Kiepenheuer.

Giddens, Anthony (1997), Jenseits von Links und Rechts: Die Zukunft Radikaler Demokratie, Frankfurt, a. M.

Giddens, Anthony (1999), Der Dritte Weg: Die Erneuerung der Sozialen Demokratie, Frankfurt, a. M.

Goldthorpe, John H., C. Lewellyn, C. Payne (1987), Social Mobility and the Class Structure in Modernd Britain, Oxford, Clarendon, 2nd edn.

Goldthorpe, John H., David Lockwood, Frank Bechhofer, Jennifer Platt (1968), The Affluent Worker in the Class Structure, London, Cambridge University Press.

Hall, Stuart, and Tony Jefferson (1977), Resistance Through Rituals: Youth Subcultures in Post-War Britain, London, Hutchinson. 
Hartmann, Michael (1998), “Homogenität und Stabilität: die soziale rekrutiertung der deutschen wirtschaftselite im europäischen vergleich", in Peter A. Berger and Michael Vester (eds.), Alte Ungleichheiten: Neue Spaltungen, Opladen, Leske/Budrich, pp. 171-187.

Herz, Thomas A. (1990), “Die Dienstklasse: Eine empirische Analyse ihrer demographischen, kulturellen und politischen Identität", in Peter A. Berger and Stefan Hradil, (eds.), Lebenslagen, Lebensstile, Göttingen: Otto Schwartz (Soziale Welt, Sonderband 7), pp. 231-252.

Lamont, Michèle (1992), Money, Morals and Manners: the Culture of French and American Upper Class, Chicago, Chicago University Press.

Lepsius, Parteiensystem, und Sozialstruktur (1973) "Zum Problem der Demokratisierung der deutschen Gesellschaft", in Gerhard A. Ritter (ed.) Deutsche Parteien vor 1919, Koeln, Kiepenheuer \& Witsch.

Marshall, G., H. Newby, D. Rose, and C. Vogler (1988), Social Class in Modern Britain, London, Hutchinson.

Merleau-Ponty, Maurice (1945, 1965), Phaenomenologie der Wahrnehmung, Berlin, de Gruyter. Mueller, Dagmar (1990), “Zum Typus der 'neuen Arbeiterinnen', Forschungsprojekt Sozialstrukturwandel und neue soziale Milieus", Hannover (working paper).

Offe, Claus (1985), “New social movements: challenging the boundaries of institutional politics", Social Research, 52 (4), pp. 817-868.

Rüschemeyer, Dietrich (1958), “Mentalität und ideologie”, in René König (ed.), Fischer Lexikon 'Soziologie', Frankfurt, a. M.: Fischer, pp. 180-184.

Rupp, Jan C. C. (1995), “Les classes populaires dans un espace social à deux dimensions", Actes de Recherche en Sciences Sociales, 109, pp. 93-98.

Rupp, Jan C. C. (1997), "Rethinking cultural and economic capital”, in John R. Hall (ed.), Reworking Class, Ithaca (N. Y.): Cornell University Press, pp. 221-241.

Savage, Mike, James Barlow, Peter Dickens, Tony Fielding (1992), Property, Bureaucracy and Culture: Middle-Class Formation in Contemporary Britain, London/New York, Routledge.

Savage, Mike (2000), Class Analysis and Social Transformation, Buckingham/Philadelphia: Open University Press.

Schumpeter, Joseph A. (1927, 1953), “Die sozialen Klassen im ethnisch homogenen Milieu", in Joseph A. Schumpeter, Aufsätze zur Soziologie, Tübingen, pp. 147-213.

SPD (1984), Planungsdaten für die Mehrheitsfähigkeit der SPD. Ein Forschungsprojekt des Vorstandes der SPD, Bonn, Parteivorstand der SPD.

'Spiegel' Verlag, Manager Magazin (Hrsg.) (1996), 'Spiegel'-Dokumentation Soll und Haben 4, Hamburg, Spiegel Verlag.

Der Stern (2000), MarktProfile, Hamburg, Stern.

Thompson, Edward Palmer (1963, 1968), The Making of the English Working Class, Harmondsworth, Penguin.

Vester, Michael (1970), Die Entstehung des Proletariats als Lernprozess, Frankfurt, Europaeische Verlagsanstalt.

Vester, Michael (1992), “Die Modernisierung der Sozialstruktur und der Wandel von Mentalitäten", in Stefan Hradil, Zischen Bewusstsein und Sein, Opladen: Leske/Budrich, pp. 223-249. 
Vester, Michael (1998), “Was wurde aus dem Proletariat?”, in Jürgen Friedrichs, M.

Rainer Lepsius, and Karl Ulrich Mayer (eds.), Die Diagnosefähigkeit der Soziologie, Opladen, Westdeutschger Verlag, pp. 164-206.

Vester, Michael (2001), "Milieus und soziale Gerechtigkeit", in Karl-Rudolf Korte and Werner Weidenfeld (eds.), Deutschland-Trendbuch, Opladen 2001, pp. 136-183.

Vester, Michael, Michael Hofmann, and Irene Zierke (1995), Soziale Milieus in Ostdeutschland, Köln, Bund.

Vester, Michael, Peter von Oertzen, Heiko Geiling, Thomas Hermann, and Dagmar Mueller (1993, 2001), Soziale Milieus im Gesellschaftlichen Strukturwandel: Zwischen Integration und Ausgrenzung, Frankfurt, Main, 2. Aufl.

Vögele, Wolfgang, Helmut Bremer, and Michael Vester, (eds.) (2002), Soziale Milieus und Kirche, Würzburg, Ergon.

Weber, Max (1921, 1964), Wirtschaft und Gesellschaft: Grundriss der Verstehenden Soziologie, Koeln/Berlin, Kiepenheuer \& Witsch.

Wiebke, Gisela (2002), “Traditionslinie von Macht und Besitz: das konservativ-gehobene Milieu", in Wolfgang Vögele, Helmut Bremer and Michael Vester (eds.), Soziale Milieus und Kirche, Wuerzburg, Ergon, pp. 297-309.

Williams, Raymond (1963), Culture and Society 1780-1950, Harmondsworth, Penguin. Williams, Raymond (1977), Marxism and Literature, Oxford, Oxford University Press. Wright, Eric Olin (1996), Class Counts, Oxford, Oxford University Press.

Michael Vester is professor of Political Sociology and co-director of the Institut für Politische Wissenschaft, Universität Hannover, Schneiderberg 50, D-30167 Hannover: E-mail: m.vester@agis.uni-hannover.de. Homepage: www.gps.uni-hannover.de/ipw/ 